\title{
Projected effect of 2000-2050 changes in climate and emissions on aerosol levels in China and associated transboundary transport
}

\author{
H. Jiang ${ }^{1,2}$, H. Liao ${ }^{1}$, H. O. T. Pye ${ }^{3}$, S. Wu ${ }^{4}$, L. J. Mickley ${ }^{5}$, J. H. Seinfeld ${ }^{6}$, and X. Y. Zhang ${ }^{7}$ \\ ${ }^{1}$ State Key Laboratory of Atmospheric Boundary Layer Physics and Atmospheric Chemistry (LAPC), \\ Institute of Atmospheric Physics, Chinese Academy of Sciences, Beijing, China \\ ${ }^{2}$ Graduate University of Chinese Academy of Sciences, Beijing, China \\ ${ }^{3}$ National Exposure Research Laboratory, Environmental Protection Agency, Research Triangle Park, North Carolina, USA \\ ${ }^{4}$ Department of Geological and Mining Engineering and Sciences and Department of Civil and Environmental Engineering, \\ Michigan Technological University, Houghton, Michigan, USA \\ ${ }^{5}$ School of Engineering and Applied Sciences, Harvard University, Cambridge, Massachusetts, USA \\ ${ }^{6}$ Departments of Chemical Engineering and Environmental Science and Engineering, California Institute of Technology, \\ Pasadena, California, USA \\ ${ }^{7}$ Key Laboratory for Atmospheric Chemistry, Chinese Academy of Meteorological Sciences, CMA, Beijing, China
}

Correspondence to: H. Liao (hongliao@mail.iap.ac.cn)

Received: 13 February 2013 - Published in Atmos. Chem. Phys. Discuss.: 11 March 2013

Revised: 17 June 2013 - Accepted: 5 July 2013 - Published: 16 August 2013

\begin{abstract}
We investigate projected 2000-2050 changes in concentrations of aerosols in China and the associated transboundary aerosol transport by using the chemical transport model GEOS-Chem driven by the Goddard Institute for Space Studies (GISS) general circulation model (GCM) 3 at $4^{\circ} \times 5^{\circ}$ resolution. Future changes in climate and emissions projected by the IPCC A1B scenario are imposed separately and together through sensitivity simulations. Accounting for sulfate, nitrate, ammonium, black carbon (BC), and organic carbon (OC) aerosols, concentrations of individual aerosol species change by -1.5 to $+0.8 \mu \mathrm{g} \mathrm{m}^{-3}$, and $\mathrm{PM}_{2.5}$ levels are projected to change by about $10-20 \%$ in eastern China as a result of 2000-2050 change in climate alone. With future changes in anthropogenic emissions alone, concentrations of sulfate, $\mathrm{BC}$, and $\mathrm{OC}$ are simulated to decrease because of assumed reductions in emissions, and those of nitrate are predicted to increase because of higher $\mathrm{NO}_{\mathrm{x}}$ emissions combined with decreases in sulfate. The net result is a predicted reduction of seasonal mean $\mathrm{PM}_{2.5}$ concentrations in eastern China by $1-8 \mu \mathrm{g} \mathrm{m}^{-3}$ (or $10-40 \%$ ) over 2000 2050. It is noted that current emission inventories for $\mathrm{BC}$ and OC over China are judged to be inadequate at present. Transboundary fluxes of different aerosol species show different sensitivities to future changes in climate and emissions. The
\end{abstract}

annual outflow of $\mathrm{PM}_{2.5}$ from eastern China to the western Pacific is estimated to change by $-7.0 \%,-0.7 \%$, and $-9.0 \%$ over $2000-2050$ owing to climate change alone, changes in emissions alone, and changes in both climate and emissions, respectively. The fluxes of nitrate and ammonium aerosols from Europe and Central Asia into western China increase over 2000-2050 in response to projected changes in emissions, leading to a $10.5 \%$ increase in annual inflow of $\mathrm{PM}_{2.5}$ to western China with future changes in both emissions and climate. Fluxes of $\mathrm{BC}$ and $\mathrm{OC}$ from South Asia to China in spring contribute a large fraction of the annual inflow of $\mathrm{PM}_{2.5}$. The annual inflow of $\mathrm{PM}_{2.5}$ from South Asia and Southeast Asia to China is estimated to change by $-8 \%,+281 \%$, and $+227 \%$ over $2000-2050$ owing to climate change alone, changes in emissions alone, and changes in both climate and emissions, respectively. While the $4^{\circ} \times 5^{\circ}$ spatial resolution is a limitation of the present study, the direction of predicted changes in aerosol levels and transboundary fluxes still provides valuable insight into future air quality. 


\section{Introduction}

Aerosols are important air pollutants that lead to negative health impacts, reductions in visibility, and changes in climate (Intergovernmental Panel on Climate Change (IPCC), 2007). Concentrations of major atmospheric aerosol species (sulfate, nitrate, ammonium, black carbon, organic carbon, and mineral dust) are especially high in China (Matsui et al., 2009; Tie and Cao, 2010; Qu et al., 2010; Cao et al., 2012), driven by a combination of direct and precursor emissions (Streets et al., 2003) and regional meteorological conditions (Zhang et al., 2010a; Zhu et al., 2012). Estimating future aerosol levels in China is essential in considerations of air quality both over China itself and in the Northern Hemisphere.

In the absence of changes in emissions of primary aerosols as well as aerosol precursors, climate change itself will influence future aerosol levels. For example, coupled climate-chemical transport modeling studies show that climate change alone can lead to increased surface ozone in anthropogenically impacted regions by $1-10 \mathrm{ppbv}$ in summertime over the coming decades, based on the IPCC future scenarios (Jacob and Winner, 2009). This increase is a result of slower transport, enhanced biogenic hydrocarbon emissions, and accelerated decomposition of peroxyacetyl nitrate (PAN) at higher temperatures (Hogrefe et al., 2004; Liao et al., 2006; Murazaki and Hess, 2006; Steiner et al., 2006; Racherla and Adams, 2008; Wu et al., 2008; Jacob and Winner, 2009; Andersson and Engardt, 2010; Chang et al., 2010; Lam et al., 2011; Katragkou et al., 2011; Langner et al., 2012; Reuten et al., 2012; Wang et al., 2013a). A warmer future climate is also predicted to influence aerosol levels over the United States and Europe by as much as $1 \mu \mathrm{g} \mathrm{m}{ }^{-3}$ through altered concentrations of atmospheric oxidants, by changed precipitation and boundary layer height, and by shifting gas-particle equilibria (Liao et al., 2006; Unger et al., 2006; Bauer et al., 2007; Jacob and Winner, 2009; Pye et al., 2009; Day and Pandis, 2011; Lam et al., 2011; Tai et al., 2012a, b; Juda-Rezler et al., 2012). Because of the enormous importance of China as a source of aerosols, a study that addresses how aerosol levels in China may change over the coming decades is called for.

Another issue that is associated with the aerosol levels in China is the future transboundary aerosol transport. A number of observational and modeling analyses have demonstrated the importance of present-day long-range transport of aerosols from East Asia. Surface observations at island sites (Huebert et al., 2001; Prospero et al., 2003) and aircraft observations in Asian outflow over the Northwest Pacific (Jordan et al., 2003; Maxwell-Meier et al., 2004) and the Northeast Pacific (Clarke et al., 2001; Price et al., 2003) have documented the spring maximum in transpacific transport. By using the global atmospheric chemical transport model GEOS-Chem, Park et al. (2003) predicted that transpacific transport contributes about $10 \%$ of the annual mean natural background surface-layer concentrations of black carbon over the United States. By using satellite measurements of aerosol optical depth over the North Pacific together with GEOS-Chem simulation, Heald et al. (2006) showed that transport from Asia led to a seasonal mean increase of surface-layer sulfate concentration of $0.16 \mu \mathrm{g} \mathrm{m}^{-3}$ (with $50 \%$ uncertainty) in the northwestern United States in spring of 2001. Chin et al. (2007) predicted an enhancement of similar magnitude in surface-layer sulfate aerosol in the western United States in 2001 by long-range aerosol transport; the annual mean contribution to sulfate concentration was estimated to be $0.1-0.2 \mu \mathrm{g} \mathrm{m}^{-3}$ using the global model GOCART. Yu et al. (2008) performed a satellite-based assessment of transpacific transport of anthropogenic and biomass burning aerosols based on 2002-2005 aerosol optical depths from the Moderate Resolution Imaging Spectroradiometer (MODIS). They estimated that about $25 \%$ of aerosol mass exported from East Asia to the northwestern Pacific Ocean can reach the west coast of North America. Two studies examined aerosol transport from Europe and South Asia to China. Chin et al. (2007) estimated that European emissions can increase the surface ammonium sulfate concentrations over eastern Asia by $0.2-0.5 \mu \mathrm{g} \mathrm{m}^{-3}$. Using the GEOS-Chem model, Zhang et al. (2010b) estimated that organic carbon aerosol from South Asia contributed $50-70 \%$ of organic carbon (OC) mass over southern China and $20-50 \%$ of OC over the western North Pacific in the middle troposphere in summer of 1998.

We present here a study to estimate the following: (1) the changes of aerosol levels in China over the years 2000-2050 as a result of projected changes in emissions and climate, (2) the changes of transboundary fluxes of aerosols into or out of China over this time period. This study builds on two previous ones. Liao et al. (2007) used the Goddard Institute for Space Studies (GISS) general circulation model (GCM) 3 to drive GEOS-Chem to simulate climatological presentday aerosol levels in the United States, and Pye et al. (2009) investigated the effects of projected climate and emissions changes on 2000-2050 sulfate-nitrate-ammonium aerosols in the United States using the same GISS Model 3/GEOSChem combination. As a basis for the present study, the IPCC emission scenario A1B (Nakicenovic and Swart, 2000) is adopted; this scenario represents a future world with rapid economic growth and introduction of new and more energyefficient technologies. GISS Model 3 global meteorological fields are used to drive the atmospheric chemical transport model GEOS-Chem for both present day (1996-2005) and years 2046-2055. Effects of climate change alone, emission changes alone, and both climate and emissions changes together on aerosol levels and transboundary fluxes are simulated. The models in the present study have a relatively coarse spatial resolution of $4^{\circ}$ latitude by $5^{\circ}$ longitude, which are not expected to capture the characteristically high concentrations of aerosols in China's major urban areas. Nevertheless, 
the direction of projected changes in aerosol levels should be correctly predicted.

The methods and model setup used to simulate presentday and year 2050 aerosols are described in Sect. 2. Section 3 evaluates simulated present-day concentrations of aerosols in China. Section 4 shows predictions of future aerosol levels over China due to changes in climate alone, emissions alone, and combined climate and emissions changes, and Sect. 5 estimates future changes in transboundary transport of aerosols to examine inflow to and outflow from China.

\section{Methods}

\subsection{GEOS-Chem/GISS models}

The atmospheric chemical transport model, GEOS-Chem (v.7-4-11, http://acmg.seas.harvard.edu/geos/), is driven by the GISS Model 3 meteorological data (Rind et al., 2007). Both the GISS Model 3 and the GEOS-Chem models have a horizontal resolution of $4^{\circ}$ latitude by $5^{\circ}$ longitude with 23 vertical layers. The interface between GEOS-Chem and the GISS meteorological fields was described by $\mathrm{Wu}$ et al. (2007) and Pye et al. (2009), and the same meteorology from the work of $\mathrm{Wu}$ et al. (2008) is used here. The GEOS-Chem model includes coupled ozone- $\mathrm{NO}_{\mathrm{x}}-$ hydrocarbon ( $\sim 80$ species, $\sim 300$ chemical reactions) (Bey et al., 2001) and aerosol chemistry. Aerosol species simulated in the GEOS-Chem model include sulfate $\left(\mathrm{SO}_{4}^{2-}\right)$ (Park et al., 2004), nitrate $\left(\mathrm{NO}_{3}^{-}\right)$(Pye et al., 2009), ammonium $\left(\mathrm{NH}_{4}^{+}\right)$, primary organic carbon (OC) and black carbon (BC) (Park et al., 2003), secondary organic aerosol (SOA), sea salt (Alexander et al., 2005), and mineral dust (Fairlie et al., 2007). SOA formation considers the oxidation of isoprene (Henze and Seinfeld, 2006), monoterpenes and other reactive volatile organic compounds (ORVOCs) (Liao et al., 2007), and aromatics (Henze et al., 2008). We focus on future changes in anthropogenic aerosols in this work; the assessment on mineral dust and sea salt aerosols will be our future work.

We perform simulations for four cases: (1) year 2000 climate and emissions, (2) 2050 climate and 2000 anthropogenic emissions of aerosol precursor and aerosols, (3) 2000 climate and 2050 anthropogenic emissions of aerosol precursor and aerosols, and (4) 2050 climate and emissions. Each case is integrated for $10 \mathrm{yr}$ (driven by 1996 2005 meteorological fields to represent year 2000 climate or by 2046-2055 meteorology to represent year 2050 climate) following $1 \mathrm{yr}$ of model spin-up. All the results presented in this paper are $10 \mathrm{yr}$ averages. Statistical analysis based on Student's two-sample $t$ test is applied to the meteorological fields and concentrations of the $10 \mathrm{yr}$ simulations.

\subsection{Emissions}

Present-day and year 2050 assumed anthropogenic emissions of aerosol precursor and aerosols are listed in Table 1. Emissions of $\mathrm{O}_{3}$ precursors (including $\mathrm{NO}_{\mathrm{x}}, \mathrm{CO}$, and non-methane volatile organic compounds (NMVOCs)) follow those in Wu et al. (2008), and those of $\mathrm{NH}_{3}$ and $\mathrm{SO}_{2}$ are taken from Pye et al. (2009). The base year for present-day anthropogenic emissions is 1999 for the United States (Wu et al., 2008) and 1998 elsewhere (Pye et al., 2009). Year 2050 anthropogenic emissions of ozone precursors, aerosol precursors, and aerosols from the IPCC A1B scenario were generated by the Integrated Model to Assess the Greenhouse Effect (IMAGE) socioeconomic model using prescribed growth factors for different regions, species, and sources (Streets et al., 2004). Ammonia emissions have an imposed seasonality that was determined as a function of temperature for one base year in this model. In present day, anthropogenic emissions of $\mathrm{NO}_{\mathrm{x}}, \mathrm{CO}, \mathrm{NMVOCs}, \mathrm{SO}_{2}, \mathrm{NH}_{3}, \mathrm{OC}$, and $\mathrm{BC}$ in eastern China are estimated to account for $12 \%, 16 \%, 12 \%, 20 \%$, $18 \%, 10 \%$, and $19 \%$, respectively, of the total global emissions. Relative to the assumed present day, year 2050 anthropogenic emissions of $\mathrm{NO}_{\mathrm{x}}, \mathrm{CO}, \mathrm{NMVOCs}, \mathrm{SO}_{2}, \mathrm{NH}_{3}, \mathrm{OC}$, and $\mathrm{BC}$ in eastern China $\left(20^{\circ}-55^{\circ} \mathrm{N}, 98^{\circ}-125^{\circ} \mathrm{E}\right)$ are estimated to change by $+72 \%,-7 \%,+86 \%,-29 \%,-12 \%$, $-40 \%$, and $-59 \%$, respectively.

Present-day and year 2050 natural emissions of ozone and aerosol precursors include $\mathrm{NO}_{\mathrm{x}}$ from lightning and soil, and biogenic hydrocarbons (Table 2), which are calculated based on the GISS Model 3 meteorological parameters. Lightning $\mathrm{NO}_{\mathrm{x}}$ emissions are parameterized based on convective cloudtop height (Price and Rind, 1992; Wang et al., 1998). Soil $\mathrm{NO}_{\mathrm{x}}$ emissions are calculated as a function of temperature, wind speed, and precipitation (Yienger and Levy, 1995). Representation of biogenic emissions follows the algorithm of Guenther et al. (1995), which considers light and temperature dependence but does not account for the suppression of isoprene emissions under elevated ambient $\mathrm{CO}_{2}$ concentrations (Rosenstiel et al., 2003) and climate-induced changes in land cover. Simulated natural emissions of $\mathrm{NO}_{\mathrm{x}}$ and biogenic hydrocarbons in eastern China are estimated to increase, respectively, by $+20 \%$ and $+22 \%$ over $2000-2050$, with the increases in biogenic emissions resulting mainly from the future increases in temperature.

For both radiative forcing in climate simulation and chemical reactions, present-day methane levels in the model are based on observations and set to $1750 \mathrm{ppb}$ with a $5 \%$ interhemispheric gradient (Wu et al., 2008). The future (20462055) methane level in GEOS-Chem follows the IPCC A1B scenario and is set to $2400 \mathrm{ppb}$ for simulations in which changes in anthropogenic emissions are considered (Pye et al., 2009). 
Table 1. Present-day and year 2050 (IPCC A1B scenario) anthropogenic emissions of aerosol precursors and aerosols. The domain of eastern China is $20^{\circ}-55^{\circ} \mathrm{N}, 98^{\circ}-125^{\circ} \mathrm{E}$.

\begin{tabular}{|c|c|c|c|c|c|c|}
\hline \multirow[b]{2}{*}{ Species } & \multicolumn{3}{|c|}{ Global } & \multicolumn{3}{|c|}{ Eastern China } \\
\hline & 2000 & 2050 & Change, $\%$ & 2000 & 2050 & Change, $\%$ \\
\hline \multicolumn{7}{|l|}{$\mathrm{NO}_{\mathrm{X}}\left(\mathrm{Tg} \mathrm{Nyr}^{-1}\right)$} \\
\hline Aircraft & 0.5 & 0.5 & 0.0 & 0.02 & 0.02 & 0.0 \\
\hline Anthropogenic & 23.7 & 47.9 & +102.0 & 3.15 & 6.21 & +97.1 \\
\hline Biomass burning & 6.5 & 8.1 & +24.6 & 0.30 & 0.34 & +13.3 \\
\hline Biofuel & 2.2 & 2.1 & -4.5 & 0.53 & 0.36 & -32.1 \\
\hline Fertilizer & 0.5 & 0.9 & +80.0 & 0.06 & 0.04 & -33.3 \\
\hline Total & 33.4 & 59.5 & +78.1 & 4.06 & 6.97 & +71.7 \\
\hline \multicolumn{7}{|l|}{$\mathrm{CO}\left(\mathrm{TgCO}_{\mathrm{yr}}{ }^{-1}\right)$} \\
\hline Anthropogenic & 420.1 & 413.6 & -1.5 & 104.26 & 94.04 & -9.8 \\
\hline Biomass burning & 458.8 & 749.6 & +63.4 & 21.69 & 34.46 & +58.9 \\
\hline Biofuel & 175.6 & 168.9 & -3.8 & 46.34 & 31.24 & -32.6 \\
\hline Total & 1054.5 & 1332.1 & +26.3 & 172.29 & 159.74 & -7.3 \\
\hline \multicolumn{7}{|c|}{ NMVOCs $\left(\mathrm{Tg} \mathrm{C} \mathrm{yr}^{-1}\right)$} \\
\hline Anthropogenic & 24.5 & 42.2 & +72.2 & 2.45 & 6.52 & +166 \\
\hline Biomass burning & 3.1 & 5.1 & +64.5 & 0.14 & 0.23 & +64.3 \\
\hline Biofuel & 7.2 & 6.9 & -4.2 & 1.65 & 1.12 & -32.1 \\
\hline Total & 34.8 & 54.2 & +55.7 & 4.24 & 7.87 & +85.6 \\
\hline \multicolumn{7}{|l|}{$\mathrm{SO}_{2}\left(\mathrm{Tg} \mathrm{S} \mathrm{yr}^{-1}\right)$} \\
\hline Aircraft & 0.1 & 0.1 & 0.0 & $<0.01$ & $<0.01$ & 0.0 \\
\hline Anthropogenic & 66.1 & 88.7 & +34.2 & 13.83 & 9.81 & -29.1 \\
\hline Biomass burning & 1.2 & 2.0 & +66.7 & 0.06 & 0.09 & +50.0 \\
\hline Biofuel & 0.3 & 0.3 & 0.0 & 0.07 & 0.05 & -28.6 \\
\hline Ship & 4.2 & 5.4 & +28.6 & 0.03 & 0.05 & +66.7 \\
\hline Total & 71.9 & 96.5 & +34.2 & 13.99 & 10.00 & -28.5 \\
\hline \multicolumn{7}{|l|}{$\mathrm{NH}_{3}\left(\mathrm{Tg} \mathrm{N} \mathrm{yr}^{-1}\right)$} \\
\hline Anthropogenic & 33.3 & 50.4 & +51.4 & 6.68 & 5.90 & -11.7 \\
\hline Biomass burning & 5.9 & 6.1 & +3.4 & 0.26 & 0.28 & +7.7 \\
\hline Biofuel & 1.6 & 1.7 & +6.3 & 0.32 & 0.22 & -31.3 \\
\hline Total & 40.8 & 58.2 & +42.6 & 7.26 & 6.40 & -11.8 \\
\hline \multicolumn{7}{|l|}{$\mathrm{OC}\left(\mathrm{Tg} \mathrm{Cyr}^{-1}\right)$} \\
\hline Anthropogenic & 2.5 & 0.9 & -64.0 & 0.58 & 0.16 & -72.4 \\
\hline Biomass burning & 21.6 & 21.8 & +0.9 & 1.10 & 1.08 & -1.8 \\
\hline Biofuel & 6.4 & 2.7 & -57.8 & 1.31 & 0.56 & -57.3 \\
\hline Total & 30.5 & 25.4 & -16.7 & 2.99 & 1.80 & -39.8 \\
\hline \multicolumn{7}{|l|}{$\mathrm{BC}\left(\mathrm{Tg} \mathrm{C} \mathrm{yr}^{-1}\right)$} \\
\hline Anthropogenic & 3.1 & 2.0 & -35.5 & 0.84 & 0.27 & -67.9 \\
\hline Biomass burning & 2.6 & 2.7 & +3.8 & 0.13 & 0.13 & 0.0 \\
\hline Biofuel & 1.5 & 0.6 & -60.0 & 0.36 & 0.15 & -58.3 \\
\hline Total & 7.2 & 5.3 & -26.4 & 1.33 & 0.55 & -58.6 \\
\hline
\end{tabular}


Table 2. Simulated changes in natural emissions due to predicted climate change (IPCC A1B scenario). The domain of eastern China is $20^{\circ}-55^{\circ} \mathrm{N}, 98^{\circ}-125^{\circ} \mathrm{E}$.

\begin{tabular}{|c|c|c|c|c|c|c|}
\hline \multirow[b]{2}{*}{ Species } & \multicolumn{3}{|c|}{ Global } & \multicolumn{3}{|c|}{ Eastern China } \\
\hline & 2000 & 2050 & Change, $\%$ & 2000 & 2050 & Change, $\%$ \\
\hline \multicolumn{7}{|l|}{$\mathrm{NO}_{\mathrm{x}}\left(\mathrm{Tg} \mathrm{N} \mathrm{yr}^{-1}\right)$} \\
\hline Lightning & 4.8 & 5.7 & +18.8 & 0.28 & 0.37 & +32.1 \\
\hline Soil & 6.7 & 7.3 & +9.0 & 0.36 & 0.40 & +11.1 \\
\hline Total & 11.5 & 13.0 & +13.0 & 0.64 & 0.77 & +20.3 \\
\hline \multicolumn{7}{|c|}{ Biogenic hydrocarbons $\left({\left.\mathrm{Tg} \mathrm{C} \mathrm{yr}^{-1}\right)}^{-1}\right.$} \\
\hline Isoprene & 432.4 & 533.2 & +23.3 & 19.31 & 23.90 & +23.8 \\
\hline Monoterpenes & 120.9 & 144.4 & +19.4 & 6.26 & 7.38 & +17.9 \\
\hline Acetone & 43.4 & 50.4 & +16.1 & 1.28 & 1.54 & +20.3 \\
\hline Propene & 12.4 & 15.2 & +22.6 & 0.55 & 0.68 & +23.6 \\
\hline Methyl Butenol & 5.4 & 6.8 & +25.9 & 1.03 & 1.30 & +26.2 \\
\hline Total & 614.5 & 750.0 & +22.1 & 28.43 & 34.80 & +22.4 \\
\hline
\end{tabular}
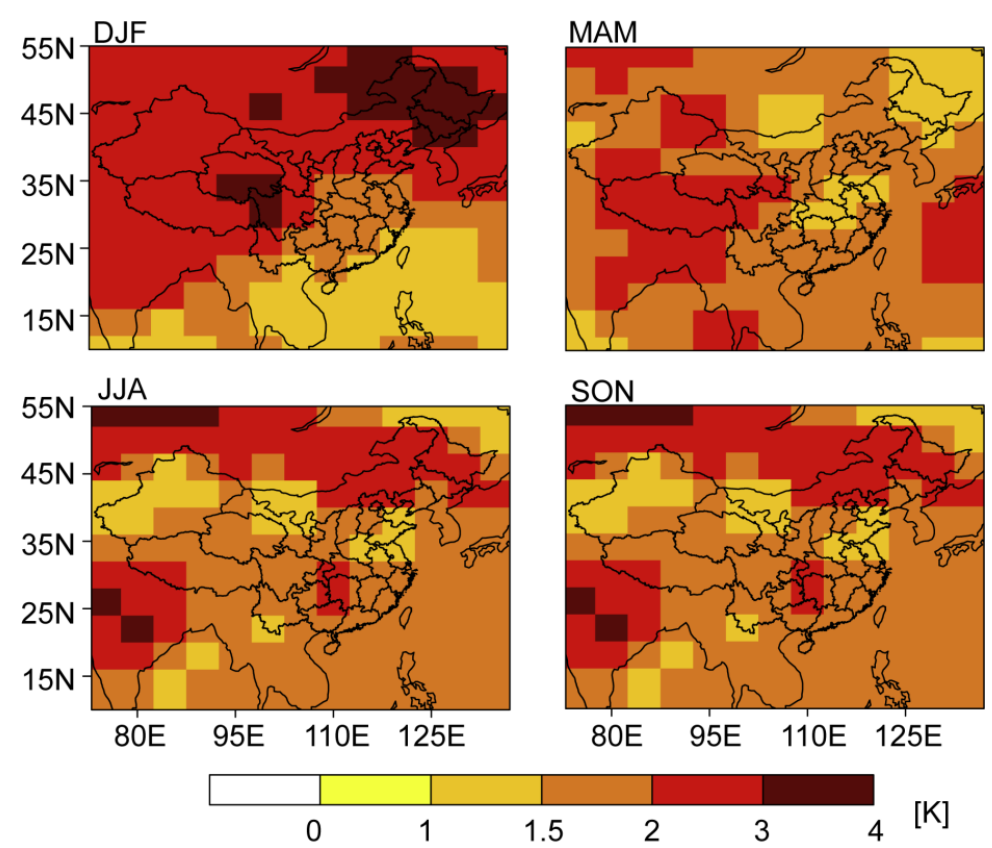

Fig. 1. Projected changes in surface air temperature (K) in China from the present day (1996-2005) to future (2046-2055) under the IPCC A1B scenario. Projected changes are all statistically significant at the $95 \%$ level, as determined by Student's two-sample $t$ test.

\subsection{Projected climate change in China over 2000-2050}

Present-day meteorological conditions from the NASA GISS Model 3 were simulated with greenhouse gas levels corresponding to years 1996-2005. Year 2046-2055 climate was obtained from a simulation in which $\mathrm{CO}_{2}$ and other greenhouse gases follow the IPCC A1B scenario. The GISS Model 3 was coupled with a "Q-flux" ocean as described in $\mathrm{Wu}$ et al. (2008). Note that the direct and indirect effects of aerosols were not considered in the simulation of
2000-2050 climate change. We have compared the GISS Model 3 predictions of present-day (1996-2005) temperature, wind, and precipitation with assimilated meteorological parameters for 1996-2005 from the Goddard Earth Observing System (GEOS)-4 of the NASA Global Modeling and Assimilation Office (GMAO) (http://acmg.seas.harvard. edu/geos/geos_sim.html). The GISS model captures fairly well the pattern and magnitude of surface air temperatures and zonal winds in China (see Supplement). Both the simulated and assimilated surface air temperatures show higher 
( a )
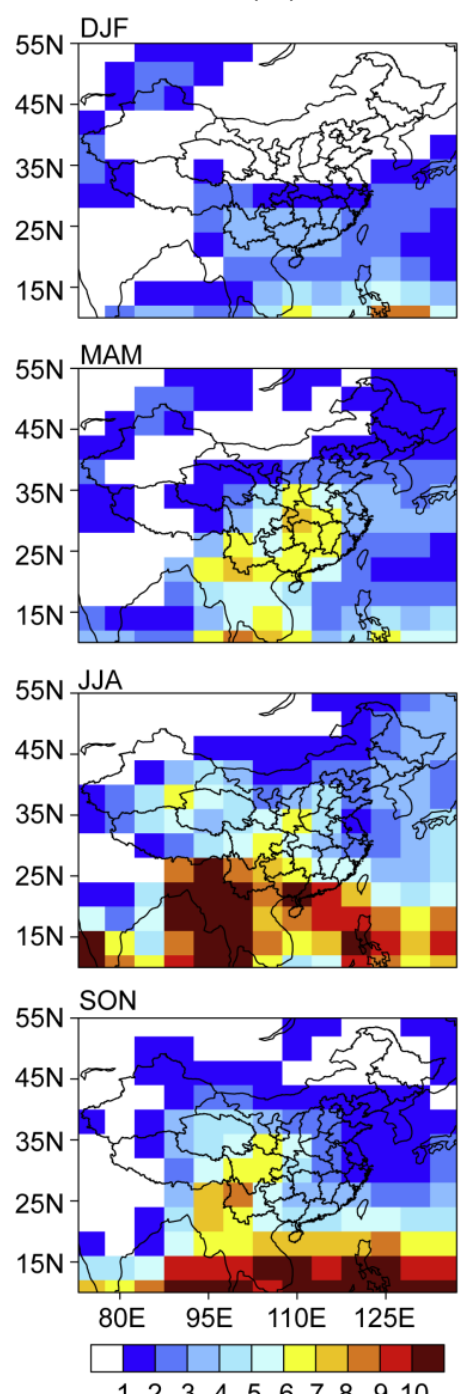

(b)
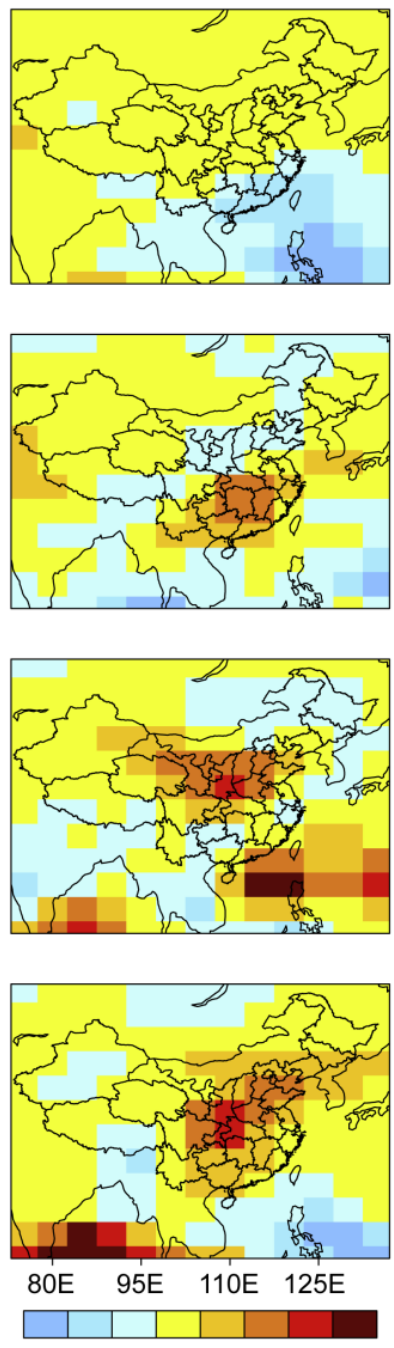

$\begin{array}{lllllll}-1 & -0.5 & 0 & 0.5 & 1 & 1.5 & 2\end{array}$ (c)
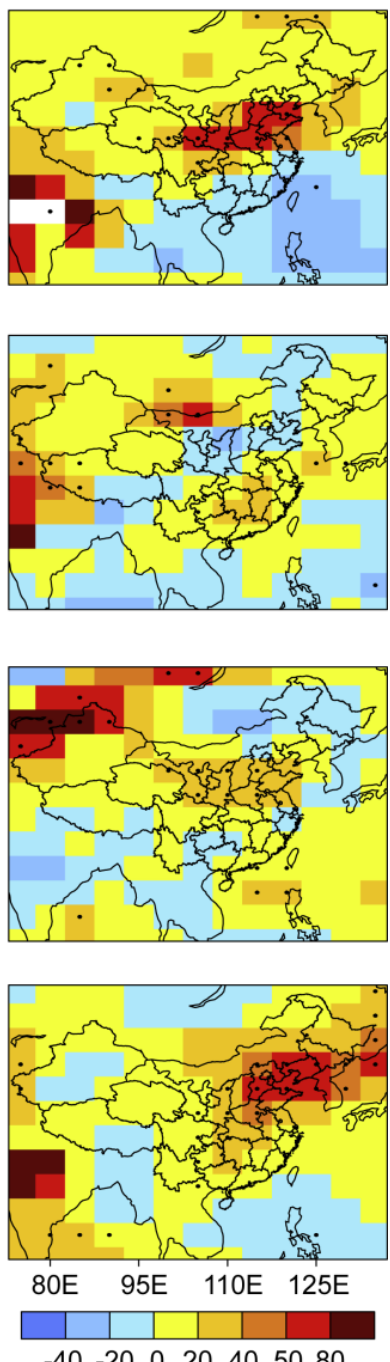

Fig. 2. (a) Simulated precipitation $\left(\mathrm{mm} \mathrm{day}^{-1}\right)$ in China in present day; (b) projected changes in precipitation $\left(\mathrm{mm} \mathrm{day}^{-1}\right)$ in China from the present day (1996-2005) to future (2046-2055) under the IPCC A1B scenario; (c) the percentage changes in precipitation relative to present day. The dotted areas in (c) are statistically significant at the $95 \%$ level, as determined by Student's two-sample $t$ test.

temperatures in southern China than in northern China and also higher temperatures in eastern China than in western China. The maximum temperatures in southeastern China are simulated to be $280-290 \mathrm{~K}$ in DJF, $290-300 \mathrm{~K}$ in MAM, $300-310 \mathrm{~K}$ in JJA, and $290-300 \mathrm{~K}$ in SON, which agree with the assimilated values in all seasons except that the assimilated maximum temperatures in southeastern China are lower than $305 \mathrm{~K}$ in JJA. Simulated zonal winds averaged over $100^{\circ}-120^{\circ} \mathrm{E}$ longitudes show maximum wind speeds of the jet stream located at $200 \mathrm{hPa}$ altitude of $60,40,20$, and $30 \mathrm{~m} \mathrm{~s}^{-1}$ in DJF, MAM, JJA, and SON, respectively, which agree closely with the assimilated values. The present-day precipitation simulated by the GISS model shows larger values in MAM and JJA than in DJF and SON, which agree with the assimilated precipitation, but the model overestimates precipitation in the middle and lower reaches of the Yangtze River in MAM whereas underestimates precipitation in that region in JJA.

Figure 1 shows the projected changes in surface air temperature in China from present day to year 2050 by longlived greenhouse gases under the IPCC A1B scenario. Over the period 2000-2050, surface air temperatures in DecemberJanuary-February (DJF) are estimated to have large increases, with values of $1.5-3 \mathrm{~K}$ in most places of China and the strongest warming of 3-4 K over the Tibetan Plateau and northeastern China. In other seasons, surface air temperatures are estimated to increase by $1-3 \mathrm{~K}$ over a large fraction of China. Warming under scenario A1B is generally 
( a )
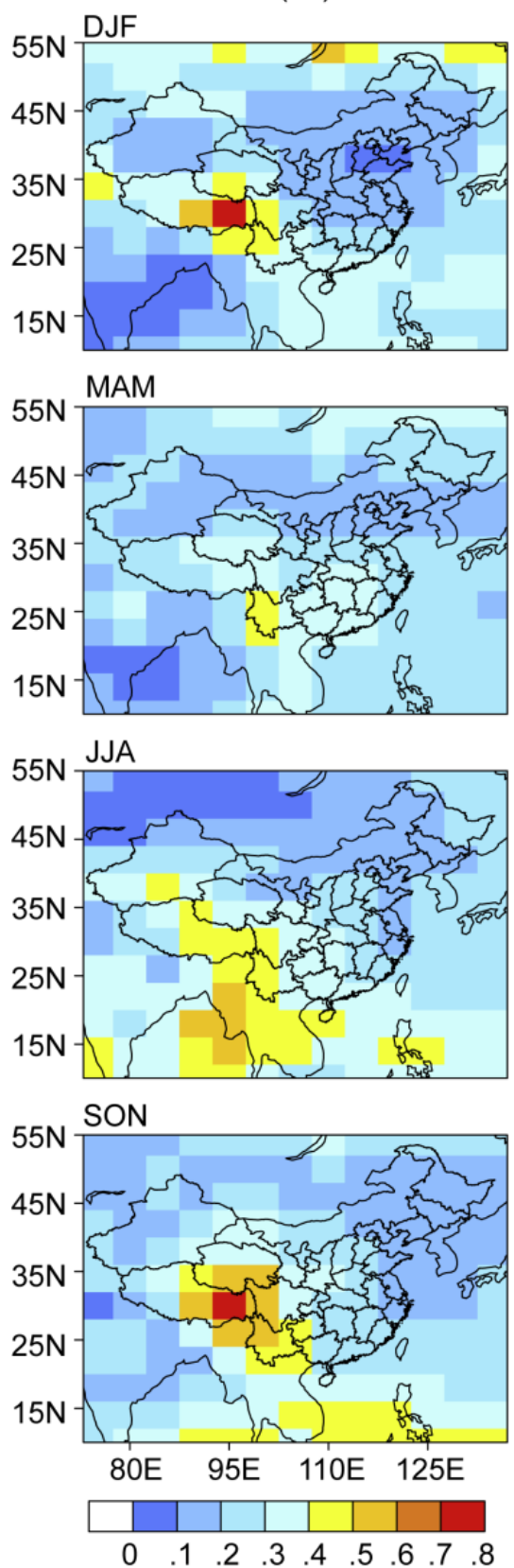

(b)
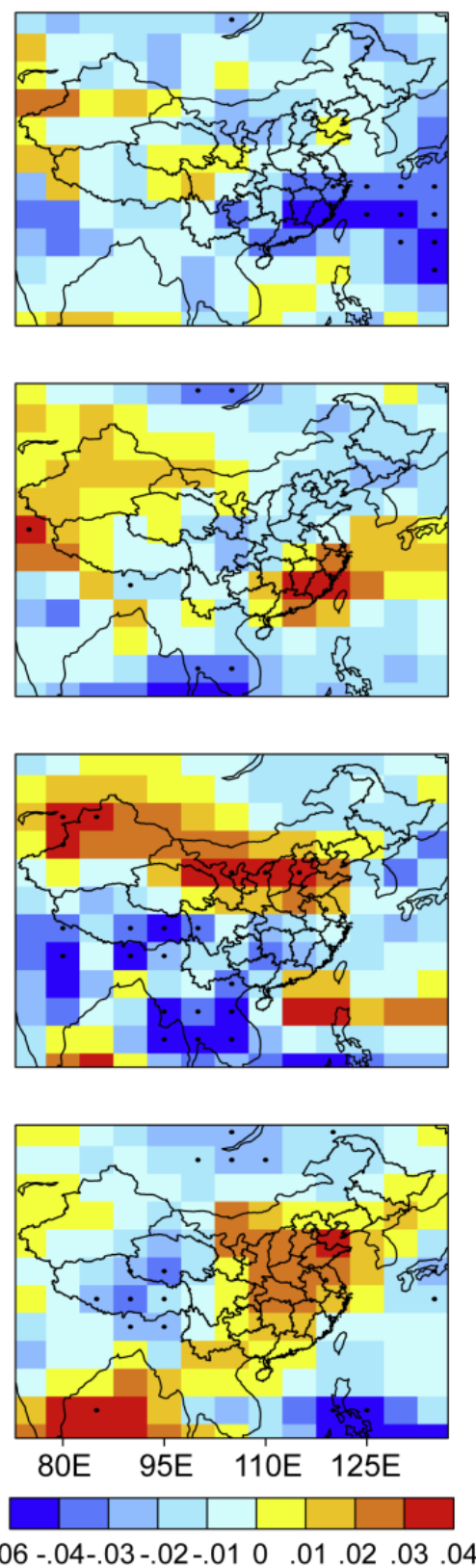

Fig. 3. (a) Simulated cloud fraction (true fraction, $1.0=$ total overcast cloud) in China in present day and (b) projected changes in cloud fraction in China from the present day (1996-2005) to future (2046-2055) under the IPCC A1B scenario. The dotted areas in (b) are statistically significant at the $95 \%$ level, as determined by Student's two-sample $t$ test.

predicted to be more pronounced than under scenario B1 and less pronounced than under A2 (IPCC, 2007).

Projected changes in precipitation in China from present day to year 2050 are shown in Fig. 2. Relative to present day, year 2050 precipitation in DJF is estimated to increase by $50-80 \%$ in northern China and decrease by about $20 \%$ in southern China; note that the present-day precipitation in DJF is the smallest among all seasons. In March-April-May
(MAM), year 2050 precipitation is estimated to increase by $20-40 \%$ in southern China where the present-day seasonal precipitation is greatest. Precipitation is predicted to increase generally in eastern China in June-July-August (JJA) and September-October-November (SON). Note that the projected patterns of precipitation changes (the increases in precipitation in northern China in DJF and the increases in precipitation in eastern China in JJA) from the GISS Model 3 
( a )
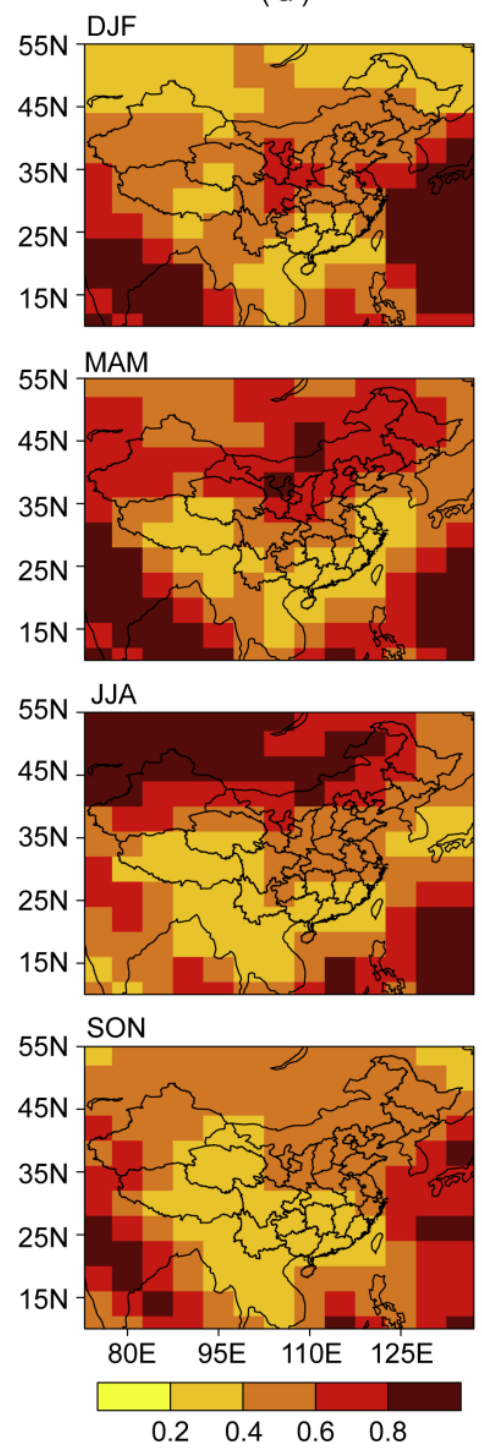

(b)
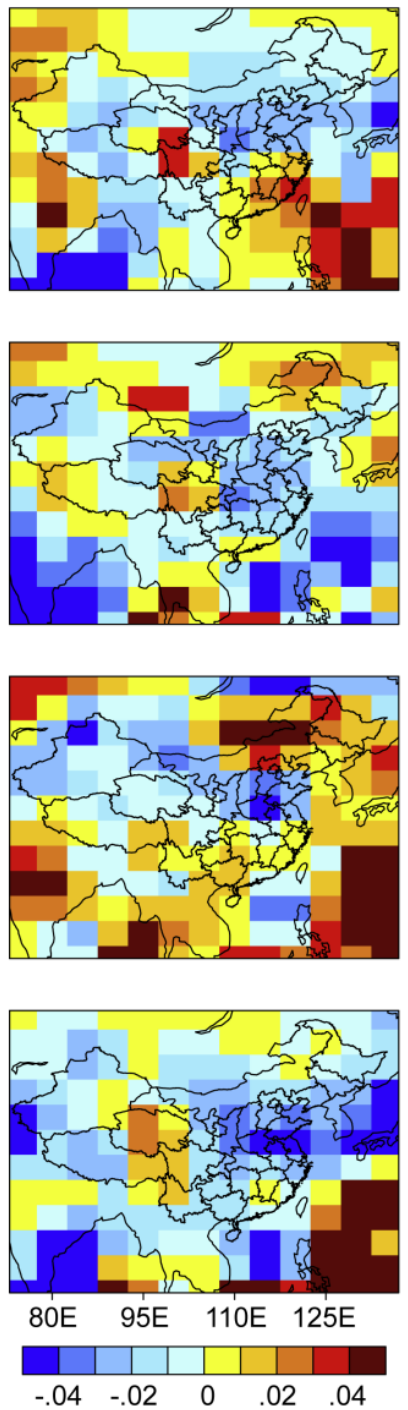

(c)
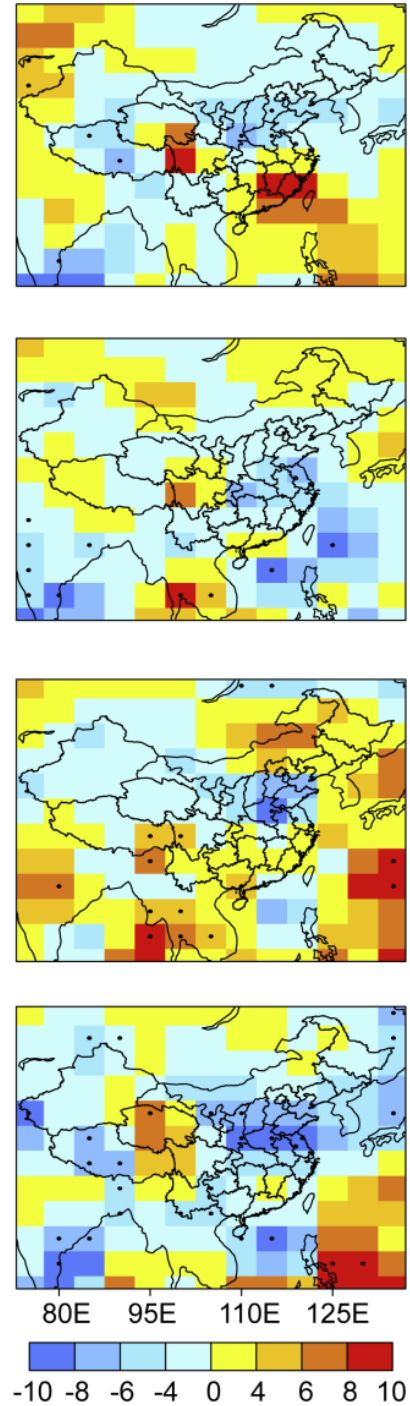

Fig. 4. (a) Simulated planetary boundary layer $(\mathrm{PBL})$ depth $(\mathrm{km})$ in China in present day; (b) projected changes in PBL depth (km) in China from the present day (1996-2005) to future (2046-2055) under the IPCC A1B scenario; (c) the percentage changes in PBL depth relative to present day. The dotted areas in (c) are statistically significant at the $95 \%$ level, as determined by Student's two-sample $t$ test.

generally agree with those from the IPCC AR4 multi-model predictions for China under the A1B scenario (IPCC, 2007). Projected changes in cloud fraction in China from present day to year 2050 are shown in Fig. 3. Changes in cloud fraction correspond well with the changes in precipitation; decreases (or increases) in clouds are associated with the decreases (or increases) in precipitation (Fig. 2).

The projected changes in the planetary boundary layer (PBL) depth in China between present day and 2050 are shown in Fig. 4. In a warmer 2050, the PBL depths over the heavily populated eastern China are predicted to decrease generally in MAM and SON (see also Supplement). Reductions in PBL depth are also predicted in northern China in
DJF and JJA. Simulated changes in the seasonal mean PBL depth in China are in the range of $\pm 10 \%$. The changes in PBL depth result from the simulated changes in atmospheric temperature (or atmospheric stability); a more unstable atmosphere leads to higher PBL depths.

\section{Simulated present-day aerosols}

\subsection{Model results}

Figure 5 shows simulated 1996-2005 seasonal mean concentrations of $\mathrm{SO}_{4}^{2-}, \mathrm{NO}_{3}^{-}, \mathrm{NH}_{4}^{+}, \mathrm{BC}, \mathrm{OC}$, and $\mathrm{PM}_{2.5}$ (sum of $\mathrm{SO}_{4}^{2-}, \mathrm{NO}_{3}^{-}, \mathrm{NH}_{4}^{+}, \mathrm{BC}$, and $\mathrm{OC}$ ) in China. Sulfate exhibits 
(a) DJF
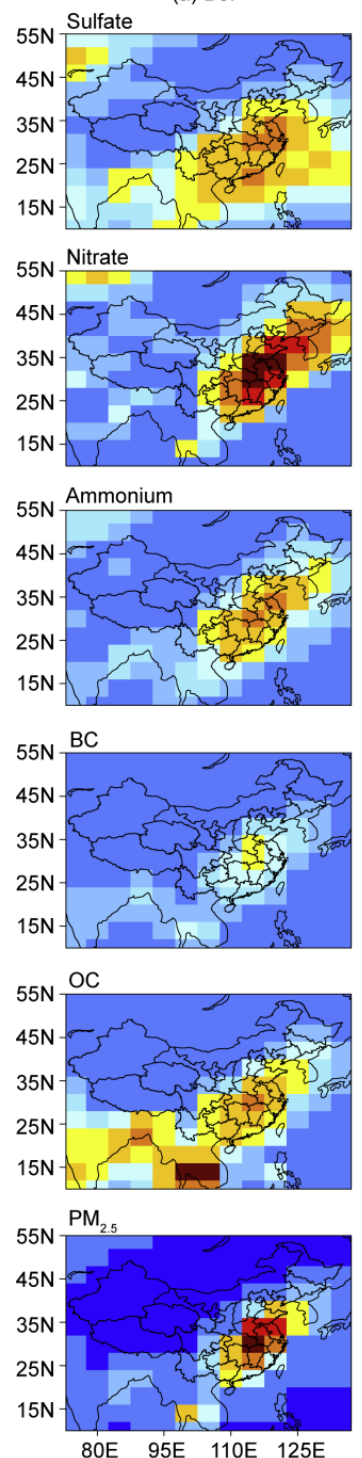

(b) MAM
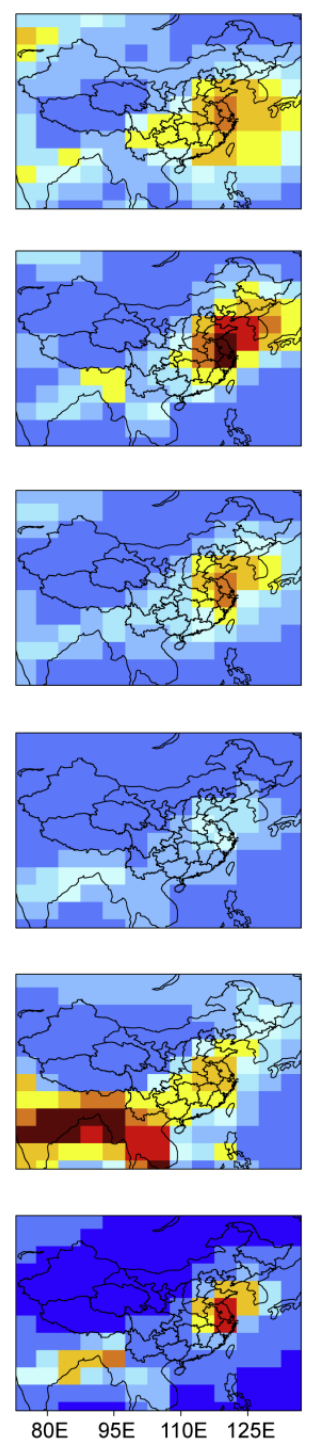

(c) JJA
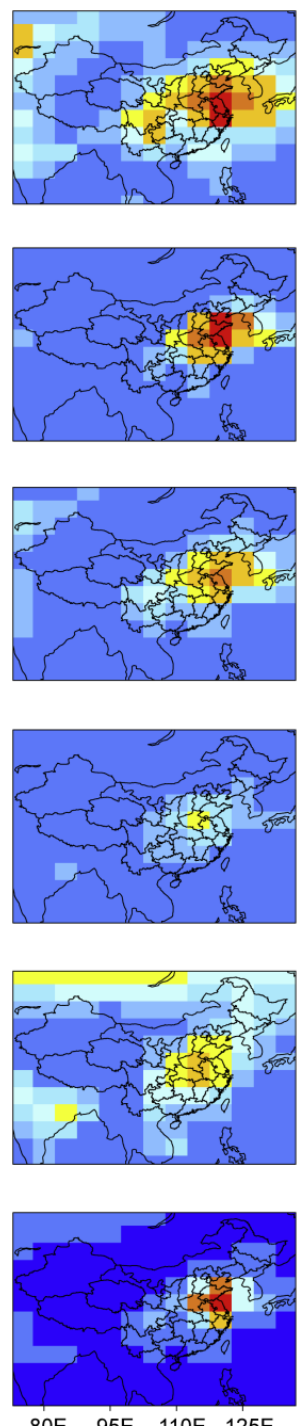

(d) SON
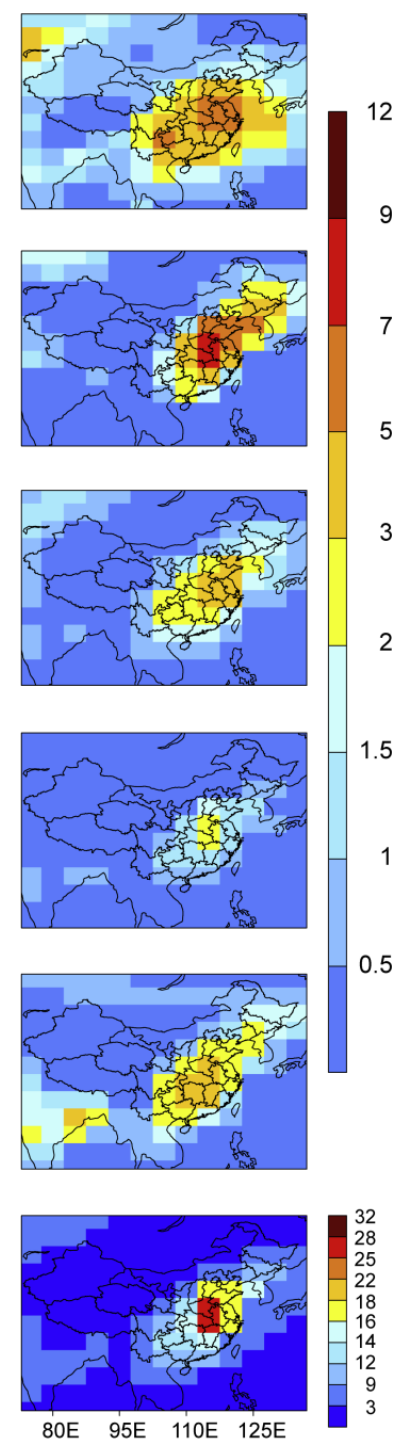

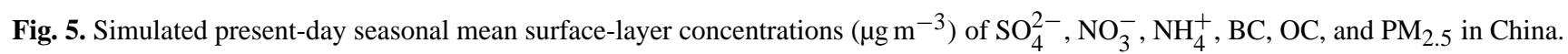

maximum concentrations of 7-9 $\mu \mathrm{g} \mathrm{m}^{-3}$ in JJA and of 5$7 \mu \mathrm{g} \mathrm{m}^{-3}$ in DJF, MAM, and SON in eastern China. Although strong photochemistry facilitates maximum sulfate formation in JJA, prevalent precipitation in southern China in JJA (Fig. 2) leads to enhanced wet removal of sulfate in that region. Simulated concentrations of $\mathrm{NO}_{3}^{-}$are generally higher than those of $\mathrm{SO}_{4}^{2-}$ in eastern China, which is likely caused by the overestimate of $\mathrm{NH}_{3}$ emissions (Wang et al., 2013b). The highest $\mathrm{NO}_{3}^{-}$concentrations of $9-12 \mu \mathrm{g} \mathrm{m}^{-3}$ are simulated in DJF because of the relatively low temperatures and precipitation. In contrast, high temperatures and large rainfall in JJA lead to the lowest $\mathrm{NO}_{3}^{-}$concentrations. Because of the excess amount of $\mathrm{NH}_{3}$ in eastern China (Wang et al., 2013b), ammonium aerosol exists predominantly as ammonium sulfate or ammonium nitrate; its concentrations are simulated to be in the range of 3-7 $\mu \mathrm{g} \mathrm{m}^{-3}$ in eastern China in all seasons. Predicted BC and OC concentrations are high in DJF and SON and low in MAM and JJA, owing to the seasonal variation of precipitation (Fig. 2). Simulated $\mathrm{PM}_{2.5}$ concentrations show the highest values of $18-32 \mu \mathrm{g} \mathrm{m}^{-3}$ in DJF and of $18-28 \mu \mathrm{g} \mathrm{m}^{-3}$ in JJA. In the surface layer, $\mathrm{NO}_{3}^{-}$is predicted to have been the most abundant aerosol species over eastern China in 1996-2005, followed by $\mathrm{SO}_{4}^{2-}, \mathrm{NH}_{4}^{+}$, OC, and $\mathrm{BC}$.

\subsection{Comparisons of simulated concentrations with measurements}

Three previous studies have compared the simulated aerosol concentrations in GEOS-Chem with measurements taken 


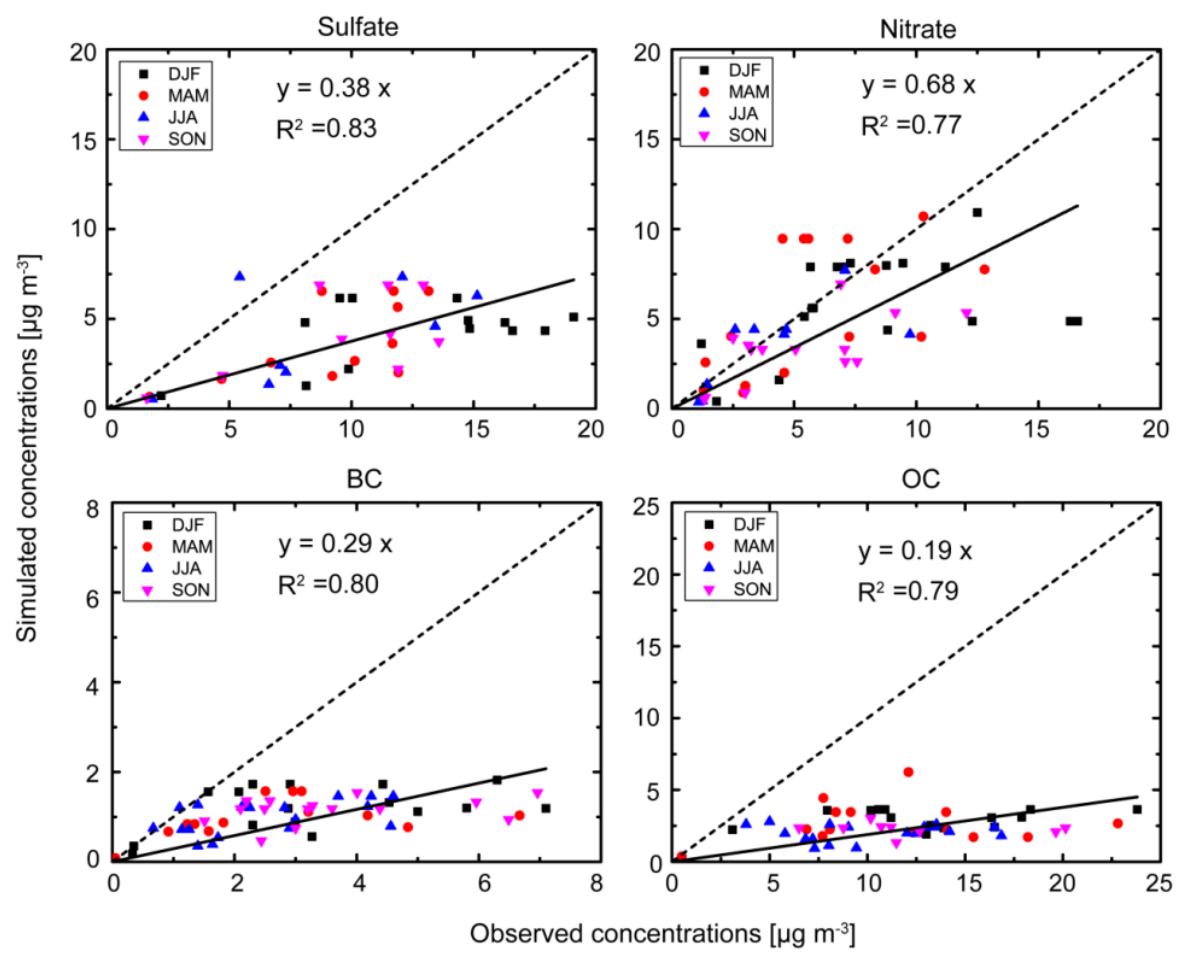

Fig. 6. Comparisons of simulated present-day concentrations of sulfate, nitrate, $\mathrm{BC}$, and $\mathrm{OC}$ aerosols with measurements. Simulated values are seasonal averages over 1996-2005. Also shown is the $1: 1$ line (dashed) and linear fit (solid line and equation). $R$ is the correlation coefficient between simulated and measured concentrations.

during 2001-2009 in China (Zhang et al., 2010a; Wang et al., 2013b; Fu et al., 2012). At a horizontal resolution of $4^{\circ}$ latitude by $5^{\circ}$ longitude, Zhang et al. (2010a) found that GEOS-Chem tends to underestimate $\mathrm{PM}_{2.5}$ aerosol concentrations in China, because measurements are usually taken in urban areas, whereas the simulated values represent grid cell averages. By using the one-way nested-grid capability of GEOS-Chem with a horizontal resolution of $0.5^{\circ}$ latitude by $0.6674^{\circ}$ longitude driven by the assimilated meteorological fields, Wang et al. (2013b) found that simulated concentrations of sulfate, nitrate, and ammonium at 22 sites in East Asia exhibited annual biases of $-10 \%,+31 \%$, and $+35 \%$, respectively, and Fu et al. (2012) reported that the simulated annual mean concentrations of $\mathrm{BC}$ and $\mathrm{OC}$ averaged over rural and background sites were underestimated by $56 \%$ and $76 \%$, respectively. Underestimation of BC in China was also found in all AEROCOM models (Koch et al., 2009), suggesting that emissions of carbonaceous aerosols are currently underestimated in China.

No publicly accessible in situ measurement network of aerosols in China exists (Chan and Yao, 2008). Therefore, we have compiled for model evaluation the monthly or seasonal mean measured concentrations of each aerosol species based on measurements reported in the literature. Most observations were conducted between 2001 and 2009 at urban sites (such as Beijing, Shanghai, and Guangzhou) and at a few rural sites (such as Fenghuangshan, Gaolanshan, and Lin'an). See the Supplement for the locations of measurements. Scatterplots of simulated versus observed seasonal mean sulfate, nitrate, $\mathrm{BC}$, and $\mathrm{OC}$ concentrations are displayed in Fig. 6. As anticipated, aerosol concentrations are generally underpredicted; the simulated concentrations of sulfate, nitrate, BC, and $\mathrm{OC}$ are about $38 \%, 68 \%, 29 \%$, and $19 \%$ of the measured values, respectively. One notes the especially low levels of BC and OC simulated, as compared with measurements, indicating the inadequacy of current emission inventories for these species. Comparisons of simulated versus observed concentrations of all aerosol species show relatively high correlation coefficients, with values of $R^{2}$ ranging from 0.77 to 0.83 . These relatively high $R^{2}$ values indicate that the model captures the spatial distributions and seasonal variations of each aerosol species despite the general low bias in simulated concentrations. Again, one should bear in mind that predicted concentrations in this study have been averaged over $4^{\circ} \times 5^{\circ}$ grid cells. 
(a) DJF
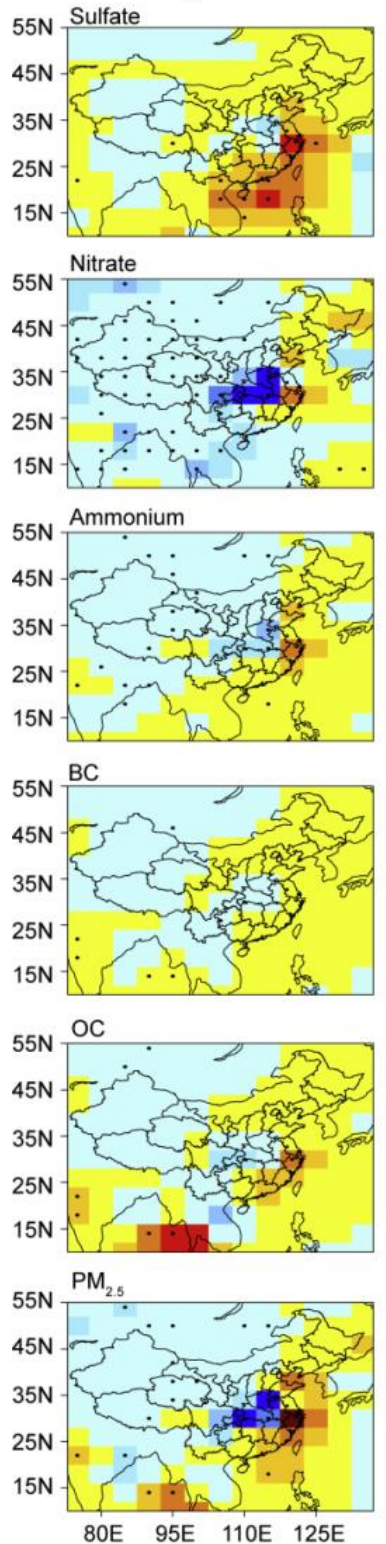

(b) MAM
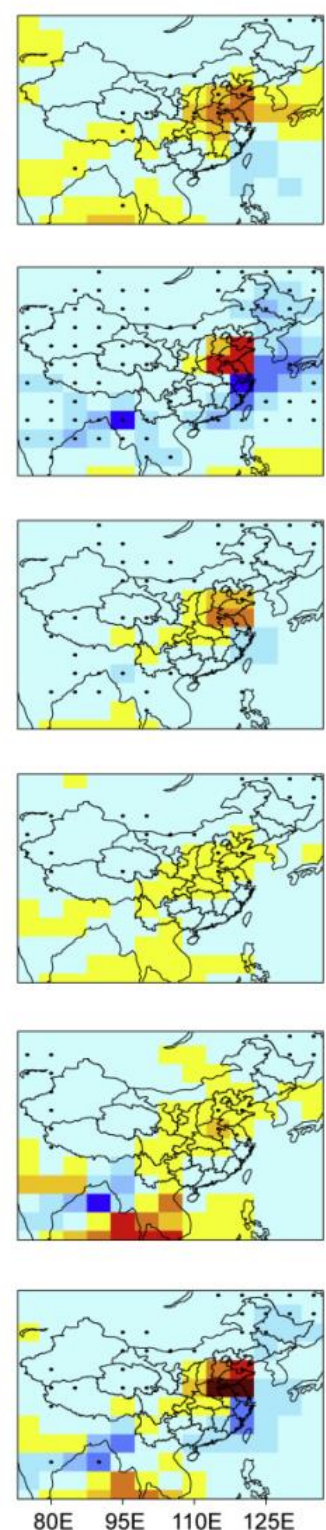

(c) JJA
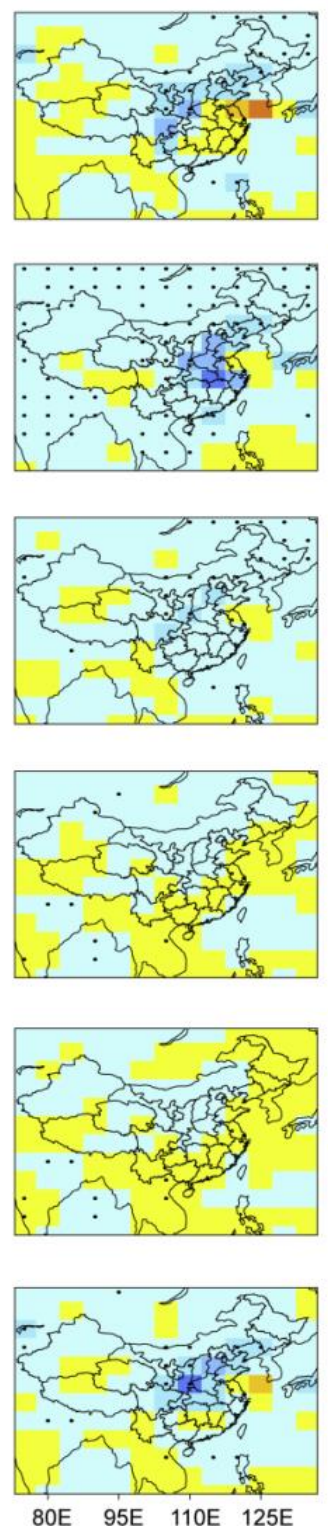

(d) SON
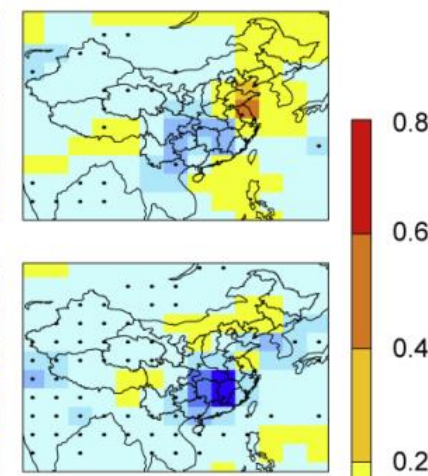

0.4
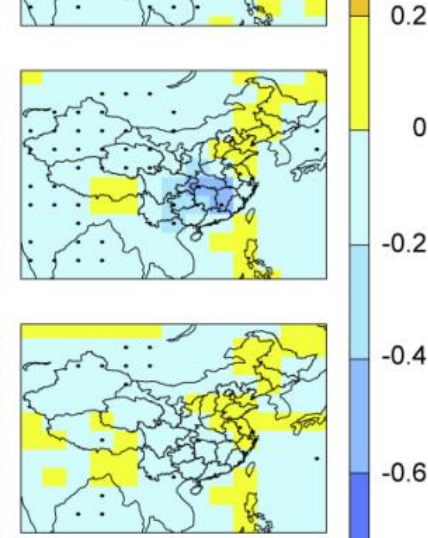

$-0.4$

$-0.6$

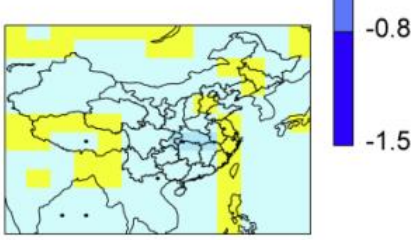

$-0.8$

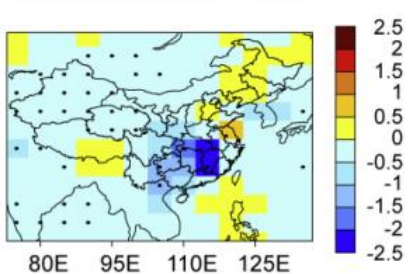

Fig. 7. Predicted changes in surface-layer concentrations of aerosols $\left(\mu \mathrm{g} \mathrm{m}^{-3}\right)$ due to changes in climate alone from the present day (19962005) to the future (2046-2055). Greenhouse gases follow the IPCC scenario A1B. Anthropogenic emissions are held at present-day values, but natural emissions may change in response to climate. The dotted areas are statistically significant at the $95 \%$ level, as determined by Student's two-sample $t$ test.

\section{Predicted 2000-2050 changes in surface-layer aerosols in China}

\subsection{Effect of changes in climate alone}

Figure 7 shows the predicted future changes in seasonal mean surface-layer aerosol concentrations as a result of the future changes in climate alone. Simulated changes in concentrations of the aerosol species are within the range of -1.5 to $+0.8 \mu \mathrm{g} \mathrm{m}^{-3}$ and exhibit similar spatial patterns in each of the four seasons. Climate-induced changes in concentrations of $\mathrm{SO}_{4}^{2-}, \mathrm{BC}$, and $\mathrm{OC}$ correspond well with the changes in precipitation in all seasons (Fig. 2), with increases (or decreases) in aerosol concentrations over places with decreases (or increases) in precipitation. Predicted reductions in nitrate and ammonium aerosol concentrations also result from the increases in temperature over 2000-2050, which lead to the shift of gas-aerosol equilibrium toward the gas phase.

As a result of the changes in individual aerosol species, $\mathrm{PM}_{2.5}$ concentrations in DJF are predicted to exhibit 
(a) DJF
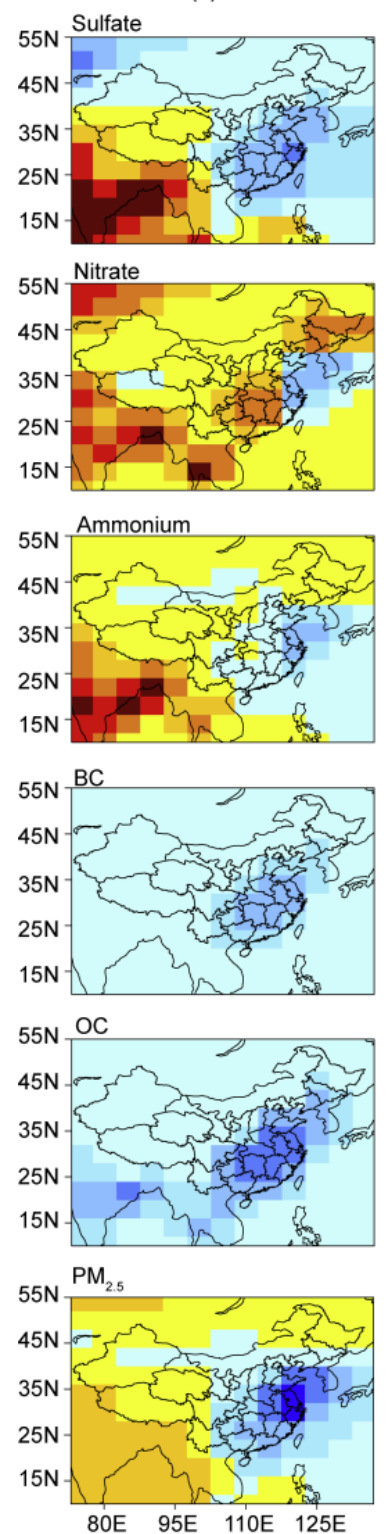

(b) MAM
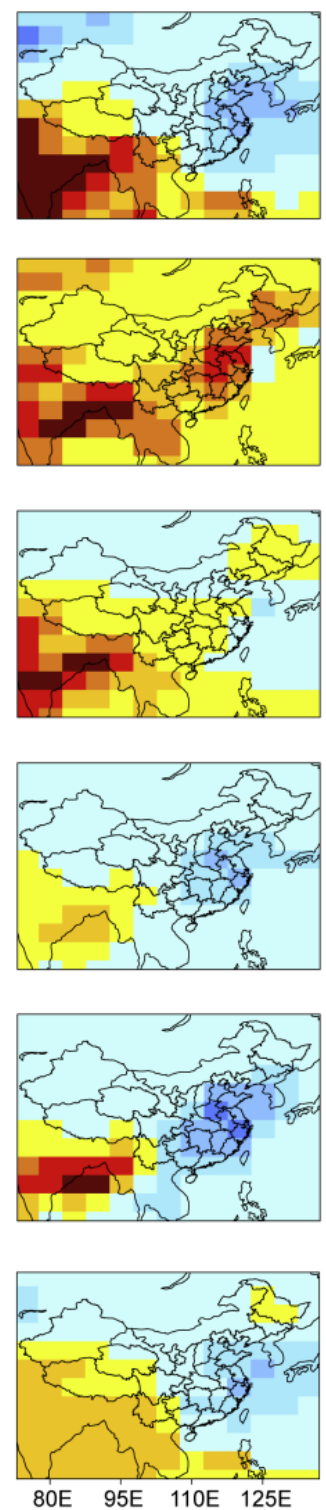

(c) JJA
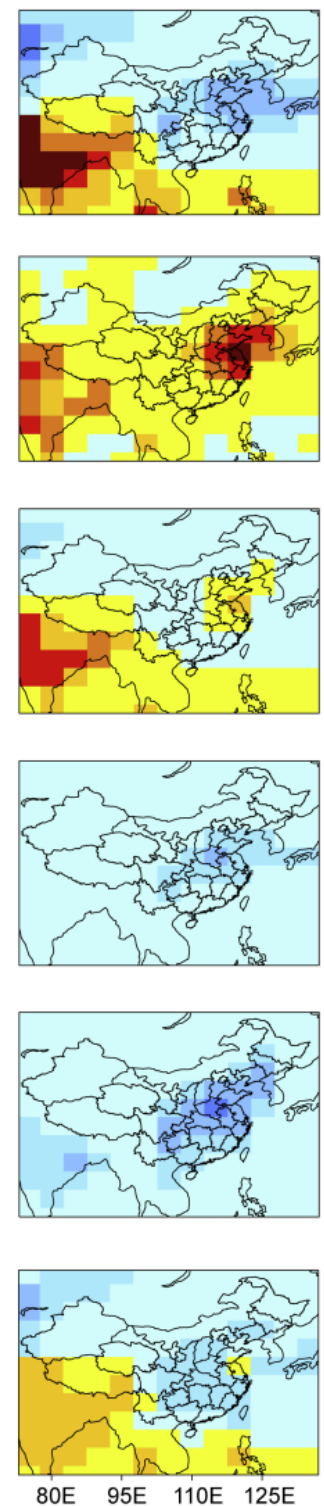

(d) SON
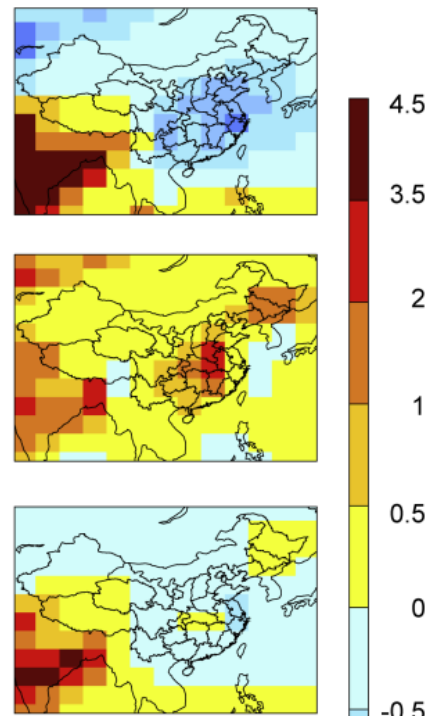

0.5

0

$-0.5$

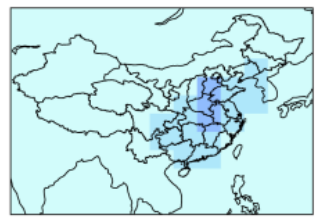

$-1$

$-2$

$-3.5$
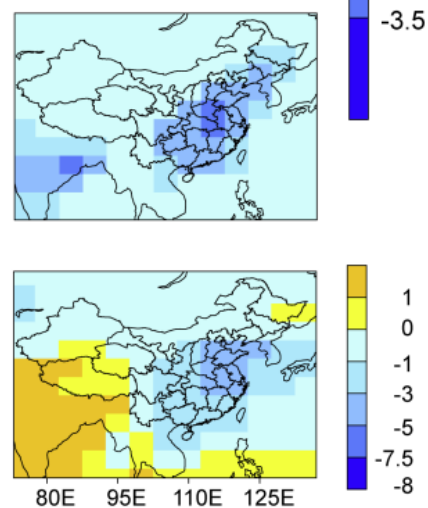

Fig. 8. Predicted changes in surface-layer concentrations of aerosols $\left(\mu \mathrm{g} \mathrm{m}^{-3}\right)$ due to changes in anthropogenic emissions alone from the present day (1996-2005) to the future (2046-2055). Almost all the changes over China are statistically significant at the 95\% level, as determined by Student's two-sample $t$ test.

increases of $1-2.5 \mu \mathrm{g} \mathrm{m}^{-3}$ along east and southeast coasts of China but decreases of $1.5-2.5 \mu \mathrm{g} \mathrm{m}^{-3}$ in central China. Increases in $\mathrm{PM}_{2.5}$ are predicted over a large fraction of eastern China in MAM, with maximum increases in the range of $1-2.5 \mu \mathrm{g} \mathrm{m}^{-3}$. $\mathrm{PM}_{2.5}$ in eastern China shows general decreases of $0.5-1.5 \mu \mathrm{g} \mathrm{m}^{-3}$ in JJA and of $1.5-2.5 \mu \mathrm{g} \mathrm{m}^{-3}$ in SON. These estimated climate-induced changes in $\mathrm{PM}_{2.5}$ concentrations over 2000-2050 represent about 10-20\% of the present-day values in those regions.

Our simulated climate-induced changes in aerosol concentrations are comparable in magnitude with those reported in other studies for other regions. Based on the IPCC A1B scenario, Tagaris et al. (2007) found a $10 \%$ decrease in $\mathrm{PM}_{2.5}$ throughout the United States and Pye et al. (2009) reported changes in annually averaged sulfate-nitrate-ammonium of up to $0.61 \mu \mathrm{g} \mathrm{m}^{-3}$ in the United States, as a result of 2000 2050 climate change alone. Under the IPCC A2 scenario, climate change over 2000-2050 alone was found to reduce $\mathrm{PM}_{2.5}$ concentrations in the United States by $-0.9 \mu \mathrm{g} \mathrm{m}^{-3}$ in the study of Avise et al. (2009). Juda-Rezler et al. (2012) reported that from 1991-2000 to 2091-2100 $\mathrm{PM}_{10}$ values over Central-Eastern Europe generally decrease, by up to 
(a) DJF
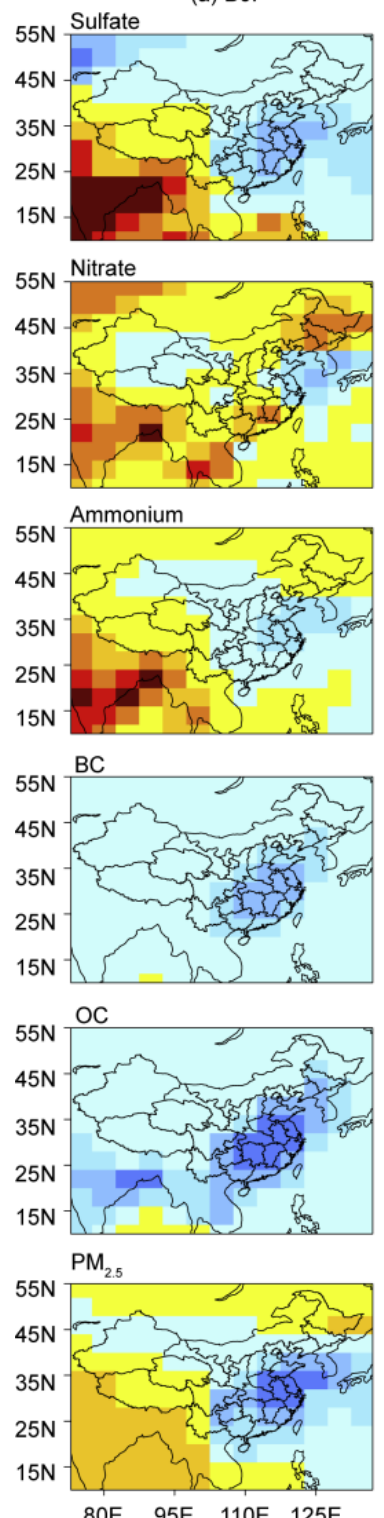

(b) MAM
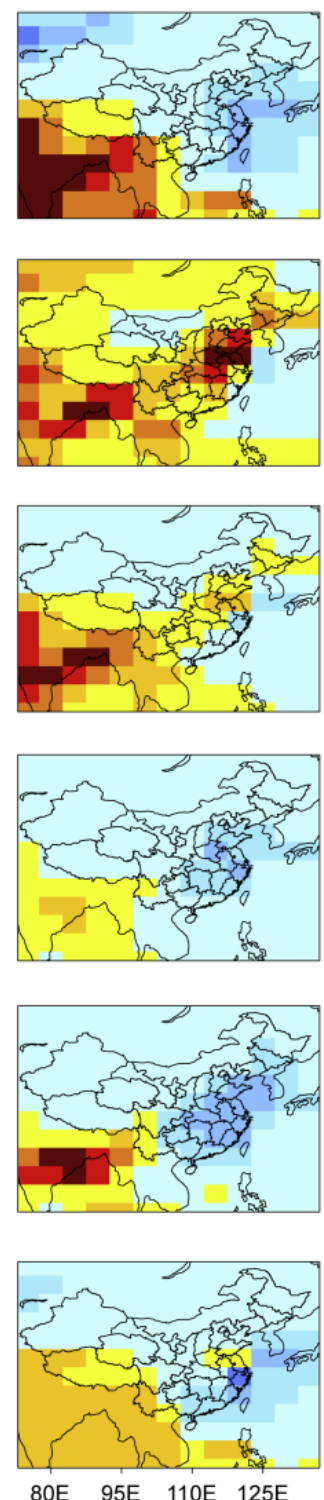

(c) JJA
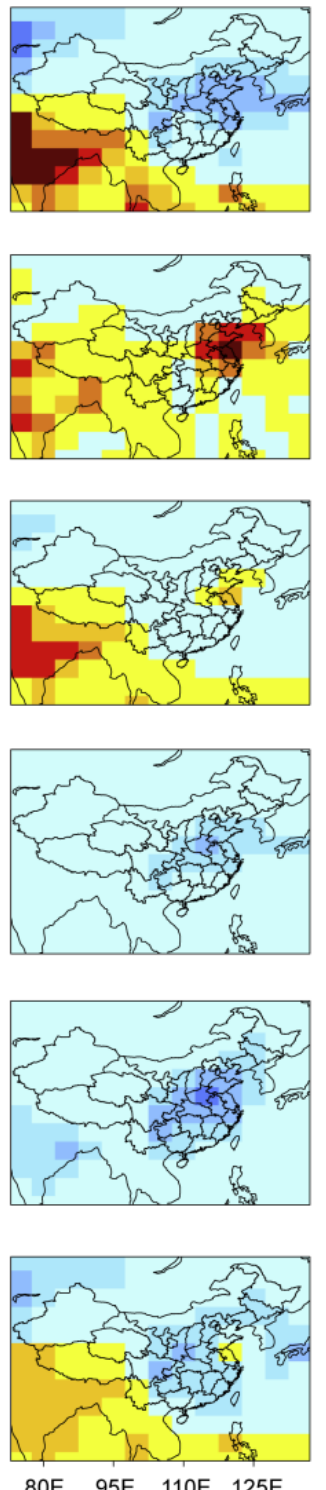

(d) SON

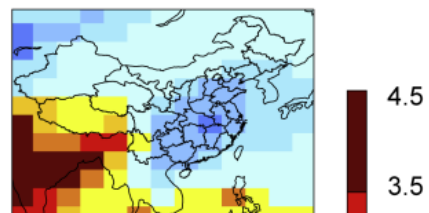

3.5
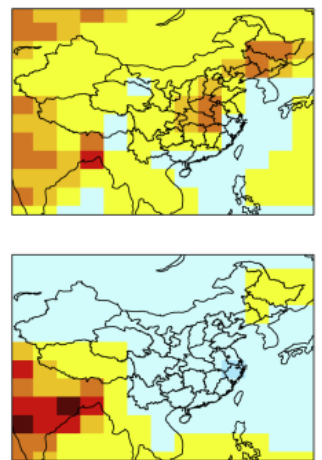

0.5

0
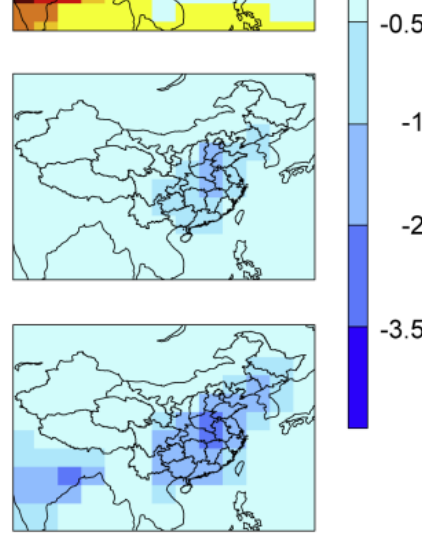

$-3.5$

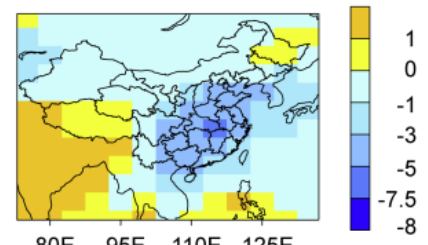

Fig. 9. Predicted changes in surface-layer concentrations of aerosols $\left(\mu \mathrm{g} \mathrm{m}^{-3}\right)$ due to changes in both climate and anthropogenic emissions from the present day (1996-2005) to the future (2046-2055). Almost all the changes over China are statistically significant at the $95 \%$ level, as determined by Student's two-sample $t$ test.

$1.5 \mu \mathrm{g} \mathrm{m}^{-3}$ in large-scale simulations and up to $3.5 \mu \mathrm{g} \mathrm{m} \mathrm{m}^{-3}$ in fine-scale simulations under the IPCC A1B scenario.

\subsection{Effect of changes in anthropogenic emissions alone}

In the IPCC A1B scenario, year 2050 annual anthropogenic emissions of $\mathrm{SO}_{2}, \mathrm{BC}$, and $\mathrm{OC}$ in eastern China are predicted to decrease by $29 \%, 59 \%$, and $40 \%$, respectively, relative to the present-day values. Future concentrations of sulfate, BC, and OC in China are hence predicted to decrease (Fig. 8). The predicted reductions in sulfate aerosol in eastern China lie within the range of $0.5-3.5 \mu \mathrm{g} \mathrm{m}^{-3}$ throughout the year. Although the simulated present-day concentrations of $\mathrm{BC}$ and $\mathrm{OC}$ are lower than those of sulfate, the decreases in $\mathrm{BC}$ and $\mathrm{OC}$ are $0.5-2 \mu \mathrm{g} \mathrm{m}^{-3}$ and $0.5-3.5 \mu \mathrm{g} \mathrm{m}^{-3}$, respectively, in eastern China.

Unlike sulfate, $\mathrm{BC}$, and $\mathrm{OC}$, based on changes in emissions alone, nitrate concentrations are predicted to increase in the future due to changing anthropogenic emissions, with the largest increases of $1-2 \mu \mathrm{g} \mathrm{m}^{-3}$ in DJF, $3.5-4.5 \mu \mathrm{g} \mathrm{m}^{-3}$ in JJA, and $2-3.5 \mu \mathrm{g} \mathrm{m}^{-3}$ in MAM and SON in eastern China. These increases can be explained by the assumed $72 \%$ increase in annual anthropogenic $\mathrm{NO}_{\mathrm{x}}$ emission over 
2000-2050 (Table 1) as well as the fact that the future reductions in $\mathrm{SO}_{2}$ favor the formation of ammonium nitrate. As a result, ammonium concentrations show increases of about $0.5 \mu \mathrm{g} \mathrm{m}^{-3}$ over those locations with large increases in nitrate.

The net effect of the changes in all aerosol species owing to changes in emissions alone is an overall decrease in $\mathrm{PM}_{2.5}$ concentrations in China except for the Tibet Plateau. Over eastern China, the projected largest decreases in $\mathrm{PM}_{2.5}$ as a result of the future changes in emissions are $7.5-8 \mu \mathrm{g} \mathrm{m}^{-3}$ (or $20-40 \%$ relative to the present-day values) in DJF, 1$5 \mu \mathrm{g} \mathrm{m}^{-3}$ (or $10-30 \%$ ) in MAM and SON, and $1-3 \mu \mathrm{g} \mathrm{m}^{-3}$ (or $10-40 \%$ ) in JJA. As noted, the increase in $\mathrm{PM}_{2.5}$ over or near the Tibet Plateau is caused by long-range transport from South Asia.

\subsection{Effect of changes in both climate and anthropogenic emissions}

Predicted future changes in aerosols as a consequence of future changes in both climate and anthropogenic emissions are summarized in Fig. 9. Concentrations of sulfate, BC, and OC in China are predicted to decrease in all seasons under future changes in both climate and anthropogenic emissions, although climate change can, to some extent, offset the effect of reductions in anthropogenic emissions on these species (Fig. 7). In eastern China, concentrations of sulfate are predicted to decrease $0.5-3.5 \mu \mathrm{g} \mathrm{m}^{-3}$ in SON and $0.5-2 \mu \mathrm{g} \mathrm{m}{ }^{-3}$ in other seasons, while those of $\mathrm{BC}$ and $\mathrm{OC}$ to decrease by $0.5-2 \mu \mathrm{g} \mathrm{m}^{-3}$ and $0.5-3.5 \mu \mathrm{g} \mathrm{m}^{-3}$, respectively, in all seasons.

For nitrate aerosol in eastern China, while climate change exerts an effect opposite to that of changes in anthropogenic emissions in DJF, JJA, and SON, the effect of climate change enhances the changes due to emissions in MAM (Fig. 7). As a result of changes in both climate and anthropogenic emissions, concentrations of nitrate in eastern China are predicted to exhibit reductions of $0.5-1 \mu \mathrm{g} \mathrm{m}^{-3}$ in DJF and increases of $0.5-4.5 \mu \mathrm{g} \mathrm{m}^{-3}$ in other seasons.

The simulated 2000-2050 changes in $\mathrm{PM}_{2.5}$ are dominated by future changes in emissions; concentrations of $\mathrm{PM}_{2.5}$ in eastern China are simulated to decrease by $3-7.5 \mu \mathrm{g} \mathrm{m}$ (or $10-30 \%$ relative to the present-day values) in DJF, 1$5 \mu \mathrm{g} \mathrm{m}^{-3}$ (or 30-40\%) in JJA, and 3-7.5 $\mu \mathrm{g} \mathrm{m} \mathrm{m}^{-3}$ (or 20$40 \%$ ) in SON. In MAM, climate change has a dominant role in influencing the future changes in aerosols in the lower reaches of Yangtze River, where increases of up to $1 \mu \mathrm{g} \mathrm{m}^{-3}$ in $\mathrm{PM}_{2.5}$ are simulated.

With reductions in $\mathrm{SO}_{2}, \mathrm{BC}$, and $\mathrm{OC}$ in eastern China over $2000-2050$ by $28.5 \%, 58.6 \%$, and $39.8 \%$ (Table 1 ), respectively, annual mean concentrations of sulfate, $\mathrm{BC}$, and $\mathrm{OC}$ over eastern China are simulated to be reduced, respectively, by $19.2 \%, 56.4 \%$, and $35.9 \%$ with future changes in emissions alone whereas by $18.5 \%, 56.6 \%$, and $36.5 \%$ with future changes in both climate and emissions. These results

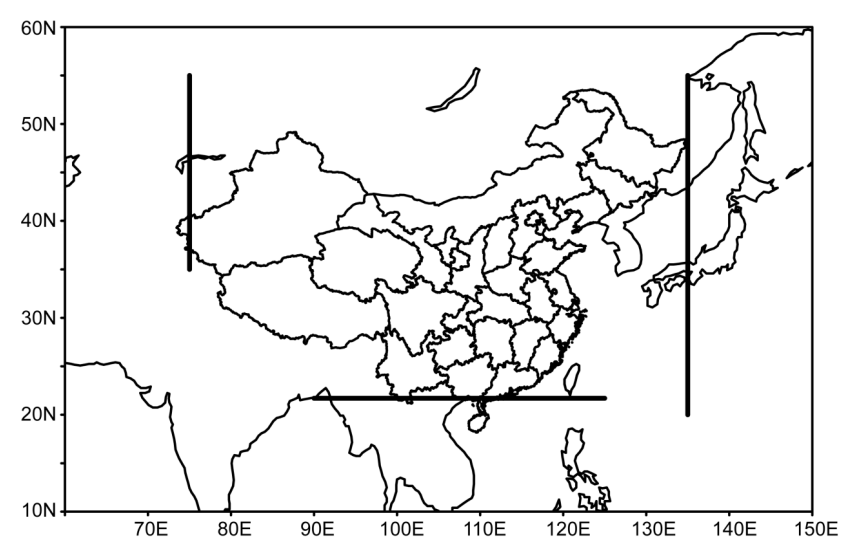

Fig. 10. The locations of the 3 vertical planes through which fluxes of transboundary aerosols are calculated: the meridional plane along $135^{\circ} \mathrm{E}$ from $20^{\circ}$ to $55^{\circ} \mathrm{N}$ to show the outflow from eastern China to the West Pacific; the meridional plane along $75^{\circ} \mathrm{E}$ from $35^{\circ}$ to $55^{\circ} \mathrm{N}$ to show the inflow from Europe and Central Asia to China; and the latitudinal plane along $21.7^{\circ} \mathrm{N}$ from $90^{\circ}$ to $125^{\circ} \mathrm{E}$ to show the transport to or from South Asia and Southeast Asia.

indicate that changes in concentrations of these aerosols are strongly driven by the changes in emissions.

\section{Simulated 2000-2050 changes in transboundary transport of aerosols}

We next estimate 2000-2050 changes in aerosol fluxes into and out of China. These fluxes of aerosols are calculated through 3 vertical planes from the surface to $100 \mathrm{hPa}$ altitude (Fig. 10): (1) the meridional plane along $135^{\circ} \mathrm{E}$ from $20^{\circ}$ to $55^{\circ} \mathrm{N}$ that captures the outflow from eastern China to the western Pacific, (2) the meridional plane along $75^{\circ} \mathrm{E}$ from $35^{\circ}$ to $55^{\circ} \mathrm{N}$ that captures the inflow from Europe and Central Asia to China, and (3) the latitudinal plane along $21.7^{\circ} \mathrm{N}$ from $90^{\circ}$ to $125^{\circ} \mathrm{E}$ to capture the transport to or from South Asia and Southeast Asia. The transboundary fluxes are calculated within the model at every time step, and the seasonal and annual values are presented here.

\subsection{Outflow of aerosols from eastern China}

\subsubsection{Estimated present-day outflow}

Simulated present-day seasonal and annual total fluxes of $\mathrm{SO}_{4}^{2-}, \mathrm{NO}_{3}^{-}, \mathrm{NH}_{4}^{+}, \mathrm{BC}, \mathrm{OC}$, and $\mathrm{PM}_{2.5}$ across the meridional plane along $135^{\circ} \mathrm{E}$ from $20^{\circ}$ to $55^{\circ} \mathrm{N}$ are listed in Table 3. Among all aerosol species, the estimated present-day outflow of $\mathrm{SO}_{4}^{2-}$ of $5.2 \mathrm{Tg} \mathrm{yr}^{-1}$ across this plane is the largest, contributing $48 \%$ of the annual outflow of $\mathrm{PM}_{2.5}$. The estimated fluxes of $\mathrm{NO}_{3}^{-}, \mathrm{NH}_{4}^{+}, \mathrm{BC}$, and $\mathrm{OC}$ account for $19 \%$, $15 \%, 5 \%$, and $13 \%$ of annual outflow of $\mathrm{PM}_{2.5}$, respectively. Aerosol fluxes show strong seasonal variations. The 

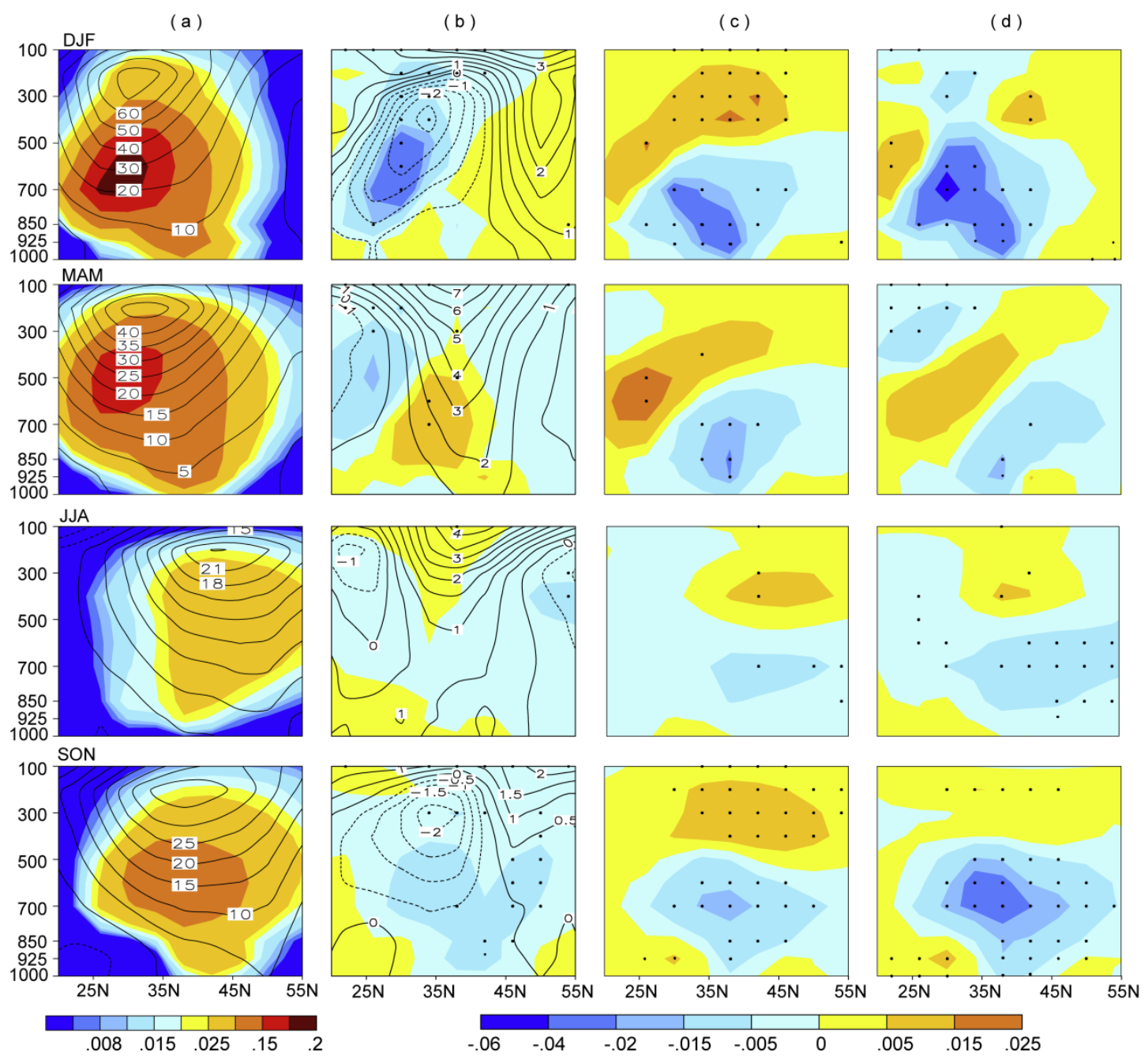

Fig. 11. (a) Simulated present-day mass fluxes of $\mathrm{PM}_{2.5}$ and zonal winds. Projected changes in mass fluxes of $\mathrm{PM}_{2.5}$ and zonal winds from the present day (1996-2005) to future (2046-2055) owing to (b) climate change alone, (c) changes in anthropogenic emissions alone, and (d) changes in both climate and anthropogenic emissions. Mass fluxes of $\mathrm{PM}_{2.5}$ are shown by shades (units: $\mathrm{Tg}$ ), and winds are represented by contours (units: $\mathrm{m} \mathrm{s}^{-1}$ ). Both mass fluxes and winds are those through the meridional plane along $135^{\circ} \mathrm{E}$ from $20^{\circ}$ to $55^{\circ} \mathrm{N}$. The dotted areas are statistically significant at the $95 \%$ level, as determined by Student's two-sample $t$ test.

outflow of $\mathrm{SO}_{4}^{2-}$ is simulated to peak in DJF, which results from the simulated high concentrations of sulfate (Fig. 5) and the strong westerlies (Fig. 11) in that season. All other aerosol species exhibit maximum outflow in MAM, a result that agrees with the conclusions from previous studies (Holzer et al., 2005). Heald et al. (2006) and Chin et al. (2007) reported that the export from Asia is most efficient in spring with nearly all East Asian air involved in transpacific transport. The outflow of aerosols is generally the weakest in JJA, as reported by Holzer et al. (2005) and Yu et al. (2008).

The pressure-latitude cross sections of the simulated fluxes of $\mathrm{PM}_{2.5}$ at $135^{\circ} \mathrm{E}$ are shown in Fig. 11. The maximum fluxes of aerosols are found at $500-700 \mathrm{hPa}$ in DJF and SON and at $400-600 \mathrm{hPa}$ in MAM and JJA. The locations of these maximum fluxes shift from $20^{\circ}-35^{\circ} \mathrm{N}$ in DJF and MAM to $30^{\circ}-50^{\circ} \mathrm{N}$ in JJA and SON, which are consistent with the changes in westerlies (Fig. 11). Our simulated vertical distributions of the strongest fluxes of aerosols agree with those reported by Wang et al. (2009), who showed that the transport to North America occurs mainly in the mid- to upper troposphere.

\subsubsection{Effect of changes in climate alone}

Simulated future changes in seasonal and annual fluxes of $\mathrm{SO}_{4}^{2-}, \mathrm{NO}_{3}^{-}, \mathrm{NH}_{4}^{+}, \mathrm{BC}, \mathrm{OC}$, and $\mathrm{PM}_{2.5}$ through the meridional plane along $135^{\circ} \mathrm{E}$ are also listed in Table 3. As a result of the climate change alone, the annual fluxes of $\mathrm{SO}_{4}^{2-}$, $\mathrm{NO}_{3}^{-}, \mathrm{NH}_{4}^{+}, \mathrm{BC}, \mathrm{OC}$, and $\mathrm{PM}_{2.5}$ are simulated to change by 
Table 3. Simulated outflow of aerosols from eastern China through the meridional plane along $135^{\circ} \mathrm{E}$ from $20^{\circ}$ to $55^{\circ} \mathrm{N}$. Numbers in the parentheses are percentage changes relative to the present-day fluxes. The units are $\mathrm{Tg}_{\mathrm{g}} \mathrm{season}^{-1}$ for seasonal fluxes and $\mathrm{Tg}_{\mathrm{yr}}^{-1} \mathrm{for}^{\mathrm{annual}}$ fluxes of whole species (e.g., $\mathrm{Tg}\left(\mathrm{SO}_{4}^{2-}\right)$ season $\left.^{-1}, \mathrm{Tg}\left(\mathrm{SO}_{4}^{2-}\right) \mathrm{yr}^{-1}\right)$.

\begin{tabular}{|c|c|c|c|c|c|c|}
\hline \multirow[b]{2}{*}{ Species } & & \multicolumn{5}{|c|}{ Outflow from eastern China } \\
\hline & & $2000^{\mathrm{a}}(\mathrm{Tg})$ & $2050^{\mathrm{b}}(\mathrm{Tg})$ & $2050^{\mathrm{c}}(\mathrm{Tg})$ & $2050^{\mathrm{d}}(\mathrm{Tg})$ & $\operatorname{NonL}^{\mathrm{e}}$ \\
\hline \multirow{5}{*}{$\mathrm{SO}_{4}^{2-}$} & DJF & 2.12 & $1.99(-6.1 \%)$ & $2.07(-2.4 \%)$ & $1.97(-7.1 \%)$ & 1.20 \\
\hline & MAM & 1.50 & $1.51(+0.7 \%)$ & $1.59(+6.0 \%)$ & $1.58(+5.3 \%)$ & 1.25 \\
\hline & JJA & 0.45 & $0.43(-4.4 \%)$ & $0.35(-22.2 \%)$ & $0.34(-24.4 \%)$ & 1.09 \\
\hline & SON & 1.12 & $1.04(-7.1 \%)$ & $0.94(-16.1 \%)$ & $0.87(-22.3 \%)$ & 1.04 \\
\hline & Annual & 5.19 & $4.97(-4.2 \%)$ & $4.95(-4.6 \%)$ & $4.76(-8.3 \%)$ & 1.07 \\
\hline \multirow{5}{*}{$\mathrm{NO}_{3}^{-}$} & DJF & 0.52 & $0.45(-13.5 \%)$ & $0.65(+25.0 \%)$ & $0.50(-3.8 \%)$ & -3.00 \\
\hline & MAM & 0.86 & $0.75(-12.8 \%)$ & $0.89(+3.5 \%)$ & $0.77(-10.5 \%)$ & 0.89 \\
\hline & JJA & 0.41 & $0.34(-17.1 \%)$ & $0.56(+36.6 \%)$ & $0.46(+12.2 \%)$ & 1.60 \\
\hline & SON & 0.32 & $0.24(-25.0 \%)$ & $0.53(+65.6 \%)$ & $0.40(+25.0 \%)$ & 1.63 \\
\hline & Annual & 2.11 & $1.78(-15.6 \%)$ & $2.63(+24.6 \%)$ & $2.13(+0.9 \%)$ & 9.50 \\
\hline \multirow{5}{*}{$\mathrm{NH}_{4}^{+}$} & DJF & 0.45 & $0.41(-8.9 \%)$ & $0.48(+6.7 \%)$ & $0.44(-2.2 \%)$ & 1.00 \\
\hline & MAM & 0.64 & $0.61(-4.7 \%)$ & $0.70(+9.4 \%)$ & $0.67(+4.7 \%)$ & 1.00 \\
\hline & JJA & 0.29 & $0.25(-13.8 \%)$ & $0.29(0.0 \%)$ & $0.26(-10.3 \%)$ & 1.33 \\
\hline & SON & 0.30 & $0.24(-20.0 \%)$ & $0.35(+16.7 \%)$ & $0.30(0.0 \%)$ & - \\
\hline & Annual & 1.68 & $1.51(-10.1 \%)$ & $1.82(+8.3 \%)$ & $1.67(-0.6 \%)$ & 3.00 \\
\hline \multirow{5}{*}{$\mathrm{BC}$} & DJF & 0.17 & $0.17(0.0 \%)$ & $0.094(-44.7 \%)$ & $0.090(-47.1 \%)$ & 0.95 \\
\hline & MAM & 0.21 & $0.21(0.0 \%)$ & $0.15(-28.6 \%)$ & $0.15(-28.6 \%)$ & 1.00 \\
\hline & JJA & 0.066 & $0.066(0.0 \%)$ & $0.034(-48.5 \%)$ & $0.033(-50.0 \%)$ & 0.97 \\
\hline & SON & 0.085 & $0.080(-5.9 \%)$ & $0.044(-48.2 \%)$ & $0.041(-51.8 \%)$ & 1.05 \\
\hline & Annual & 0.53 & $0.53(0.0 \%)$ & $0.32(-39.6 \%)$ & $0.31(-41.5 \%)$ & 0.95 \\
\hline \multirow{5}{*}{$\mathrm{OC}$} & DJF & 0.37 & $0.34(-8.1 \%)$ & $0.24(-35.1 \%)$ & $0.22(-40.5 \%)$ & 1.07 \\
\hline & MAM & 0.64 & $0.62(-3.1 \%)$ & $0.58(-9.4 \%)$ & $0.57(-10.9 \%)$ & 1.14 \\
\hline & JJA & 0.17 & $0.17(0.0 \%)$ & $0.12(-29.4 \%)$ & $0.12(-29.4 \%)$ & 1.00 \\
\hline & SON & 0.16 & $0.15(-6.3 \%)$ & $0.095(-40.6 \%)$ & $0.086(-46.3 \%)$ & 1.01 \\
\hline & Annual & 1.34 & $1.28(-4.5 \%)$ & $1.04(-22.4 \%)$ & $1.00(-25.4 \%)$ & 1.06 \\
\hline \multirow{5}{*}{$\mathrm{PM}_{2.5}$} & DJF & 3.63 & $3.36(-7.4 \%)$ & $3.53(-2.8 \%)$ & $3.22(-11.3 \%)$ & 0.90 \\
\hline & MAM & 3.85 & $3.70(-3.9 \%)$ & $3.92(+1.8 \%)$ & $3.73(-3.1 \%)$ & 0.67 \\
\hline & JJA & 1.38 & $1.26(-8.7 \%)$ & $1.35(-2.2 \%)$ & $1.22(-11.6 \%)$ & 0.94 \\
\hline & SON & 1.98 & $1.76(-11.1 \%)$ & $1.96(-1.0 \%)$ & $1.69(-14.6 \%)$ & 0.83 \\
\hline & Annual & 10.84 & $10.08(-7.0 \%)$ & $10.76(-0.7 \%)$ & $9.86(-9.0 \%)$ & 0.86 \\
\hline
\end{tabular}

a Seasonal and annual total fluxes averaged over $1996-2005 ;{ }^{b}$ year 2050 fluxes simulated with climate change alone; ${ }^{c}$ year 2050 fluxes simulated with changes in anthropogenic emissions alone; ${ }^{\mathrm{d}}$ year 2050 fluxes simulated with changes in both climate and anthropogenic emissions; ${ }^{\mathrm{e}} \mathrm{NonL}=\frac{\left(2050^{\mathrm{b}}-2000^{\mathrm{a}}\right)+\left(2050^{\mathrm{c}}-2000^{\mathrm{a}}\right)}{2050^{\mathrm{d}}-2000^{\mathrm{a}}}$.

$-4.2 \%,-15.6 \%,-10.1 \%, 0.0 \%,-4.5 \%$, and $-7.0 \%$, respectively, relative to the present-day values. Nitrate aerosol outflow is projected to exhibit the largest reduction, because nitrate aerosol concentrations in China decrease significantly in a warmer climate (Fig. 7). The fluxes of all aerosol species show reductions in all seasons except a small increase $(0.7 \%)$ in flux of $\mathrm{SO}_{4}^{2-}$ in MAM.

\subsubsection{Effect of changes in anthropogenic emissions alone}

Annual fluxes of $\mathrm{SO}_{4}^{2-}, \mathrm{NO}_{3}^{-}, \mathrm{NH}_{4}^{+}, \mathrm{BC}, \mathrm{OC}$, and $\mathrm{PM}_{2.5}$ are simulated to change by $-4.6 \%,+24.6 \%,+8.3 \%,-39.6 \%$, $-22.4 \%$, and $-0.7 \%$, respectively (Table 3 ), as a result of the changes in anthropogenic emissions alone. While nitrate and ammonium outflow fluxes exhibit large increases owing to the projected increases in concentrations in China (Fig. 8), the fluxes of $\mathrm{SO}_{4}^{2-}, \mathrm{BC}$, and $\mathrm{OC}$ decrease, corresponding to the future decreases in concentrations of these species (Fig. 8). Consequently, the annual outflow of $\mathrm{PM}_{2.5}$ is estimated to exhibit a modest change of $-0.7 \%$ over $2000-2050$ as a result of changes in emissions alone.

\subsubsection{Effect of changes in both climate and anthropogenic emissions}

Simulated year 2050 outflow fluxes of aerosols through the meridional plane along $135^{\circ} \mathrm{E}$ from $20^{\circ}$ to $55^{\circ} \mathrm{N}$ with the future changes in both anthropogenic emissions and climate are listed in Table 3. The annual fluxes of $\mathrm{SO}_{4}^{2-}, \mathrm{NO}_{3}^{-}, \mathrm{NH}_{4}^{+}$, 
$\mathrm{BC}, \mathrm{OC}$, and $\mathrm{PM}_{2.5}$ are simulated to change by $-8.3 \%$, $+0.9 \%,-0.6 \%,-41.5 \%,-25.4 \%$, and $-9.0 \%$, respectively. Climate change mitigates the effects of increases in $\mathrm{NO}_{\mathrm{x}}$ emissions on annual fluxes of $\mathrm{NO}_{3}^{-}$and $\mathrm{NH}_{4}^{+}$, but slightly enhances the effects of reductions in emissions of $\mathrm{SO}_{2}, \mathrm{BC}$, and $\mathrm{OC}$ on outflow of $\mathrm{SO}_{4}^{2-}, \mathrm{BC}$, and $\mathrm{OC}$.

With all aerosol species accounted for, the 2000-2050 changes in seasonal and annual outflow fluxes of $\mathrm{PM}_{2.5}$ resulting from future climate alone always exceed those caused by future changes in emissions alone (Table 3 ), indicating that future climate change can be influential in estimates of future intercontinental transport of aerosols.

It is of interest to examine the rate of nonlinearity of changes in aerosol fluxes with respect to the changes in climate and emissions. The last column of Table 3 shows the rate of nonlinearity defined as NonL $=$ (Change in flux by climate change alone + Change in flux by changes in emissions alone)/Change in flux by changes in both climate and emissions. Values of NonL of seasonal and annual outflow aerosol fluxes mostly deviate from 1.0 (perfect linearity), with absolute values ranging from 0.67 to 9.5 .

\subsection{Inflow of aerosols to western China}

\subsubsection{Present-day inflow}

Simulated present-day seasonal and annual fluxes of aerosols through the meridional plane along $75^{\circ} \mathrm{E}$ from $35^{\circ}$ to $55^{\circ} \mathrm{N}$ are listed in Table 4. On an annual basis, the estimated fluxes of $\mathrm{SO}_{4}^{2-}, \mathrm{NO}_{3}^{-}, \mathrm{NH}_{4}^{+}, \mathrm{BC}$, and $\mathrm{OC}$ are 2.3, 0.6, 0.6, 0.1, and $0.3 \mathrm{Tg}$, respectively. The annual inflow of $\mathrm{PM}_{2.5}$ is $3.9 \mathrm{Tg}$, which is about $35 \%$ of the annual outflow of $\mathrm{PM}_{2.5}$ from eastern China. The inflow of $\mathrm{SO}_{4}^{2-}$ peaks in DJF, when simulated $\mathrm{SO}_{4}^{2-}$ concentrations are high in Europe, and in MAM, when the westerlies are strong (Fig. 12). The fluxes of $\mathrm{NH}_{4}^{+}$, $\mathrm{BC}, \mathrm{OC}$, and $\mathrm{PM}_{2.5}$ all peak in MAM because of the dominant effect of strong westerlies in this season. The inflow of $\mathrm{NO}_{3}^{-}$is largest in JJA, when simulated $\mathrm{NO}_{3}^{-}$concentrations are highest in Europe (not shown).

The pressure-latitude cross sections of the simulated fluxes of $\mathrm{PM}_{2.5}$ at $75^{\circ} \mathrm{E}$ are shown in Fig. 12. The fluxes of aerosols are the largest north of $40^{\circ} \mathrm{N}$, which is the principal predicted transport path from Europe. The strongest inflow of all aerosol species is located at about $700 \mathrm{hPa}$ altitude.

\subsubsection{Effect of changes in climate alone}

Relative to the present-day values, the annual fluxes of $\mathrm{SO}_{4}^{2-}, \mathrm{NO}_{3}^{-}, \mathrm{NH}_{4}^{+}, \mathrm{BC}, \mathrm{OC}$, and $\mathrm{PM}_{2.5}$ through the meridional plane along $75^{\circ} \mathrm{E}$ from $35^{\circ}$ to $55^{\circ} \mathrm{N}$ are simulated to change by $-0.9 \%,-25.4 \%,-11.5 \%,-7.1 \%,-6.7 \%$, and $-5.9 \%$, respectively, as a result of the climate change alone. As expected, the warmer future temperatures contribute to large reductions of 20-29\% in estimated seasonal mean inflow of nitrate. The flux of $\mathrm{SO}_{4}^{2-}$ is simulated to increase by
$5.1 \%$ in DJF, as a result of the future stronger westerlies in DJF (Fig. 12). In MAM, JJA, and SON, the westerlies show reductions in wind speed around $700 \mathrm{hPa}$ (Fig. 12), leading to reductions in inflow of all aerosol species (Table 4).

\subsubsection{Effect of changes in anthropogenic emissions alone}

The annual fluxes of $\mathrm{SO}_{4}^{2-}, \mathrm{NO}_{3}^{-}, \mathrm{NH}_{4}^{+}, \mathrm{BC}, \mathrm{OC}$, and $\mathrm{PM}_{2.5}$ are simulated to change by $+1.7 \%,+91.5 \%,+39.3 \%$, $-28.6 \%,-23.3 \%$, and $+19.5 \%$, respectively (Table 4 ), as a result of the future changes in anthropogenic emissions alone. The magnitudes of changes in fluxes of $\mathrm{NO}_{3}^{-}, \mathrm{NH}_{4}^{+}$, $\mathrm{BC}, \mathrm{OC}$, and $\mathrm{PM}_{2.5}$ by anthropogenic emissions alone are generally larger than those of changes by climate change alone on either a seasonal or annual mean basis. As a result of future changes in emissions, the seasonal fluxes of $\mathrm{NO}_{3}^{-}$and $\mathrm{NH}_{4}^{+}$show large increases of $68-146 \%$ and $25-$ $50 \%$, respectively, while those of $\mathrm{BC}$ and $\mathrm{OC}$ show large decreases of $18-30 \%$ and $12-34 \%$, respectively, and the inflow of $\mathrm{PM}_{2.5}$ is predicted to increase by about $20 \%$ in all seasons (Table 4).

\subsubsection{Effect of changes in both climate and anthropogenic emissions}

Year 2050 inflow fluxes of aerosols through the meridional plane along $75^{\circ} \mathrm{E}$ calculated with the future changes in both anthropogenic emissions and climate are listed in Table 4. The annual fluxes of $\mathrm{SO}_{4}^{2-}, \mathrm{NO}_{3}^{-}, \mathrm{NH}_{4}^{+}, \mathrm{BC}$, and $\mathrm{OC}$ are simulated to change by $+0.9 \%,+49.2 \%,+27.9 \%,-29.3 \%$, and $-30.0 \%$, respectively. Climate change mitigates the effects of increases in $\mathrm{NO}_{\mathrm{x}}$ emissions on annual fluxes of $\mathrm{NO}_{3}^{-}$ and $\mathrm{NH}_{4}^{+}$, but enhances the effects of changes in emissions of $\mathrm{BC}$ and $\mathrm{OC}$. As a net result of the changes in inflow of all aerosol species, the annual inflow of $\mathrm{PM}_{2.5}$ to western China is projected to increase by $10.5 \%$ over 2000-2050 with future changes in both emissions and climate.

\subsection{Transport of aerosols to/from southern China}

\subsubsection{Present-day transport}

The simulated present-day seasonal and annual fluxes of aerosols through the latitudinal plane along $21.7^{\circ} \mathrm{N}$ from $90^{\circ}-125^{\circ} \mathrm{E}$ are listed in Table 5. The annual fluxes of $\mathrm{SO}_{4}^{2-}$, $\mathrm{NO}_{3}^{-}, \mathrm{NH}_{4}^{+}, \mathrm{BC}, \mathrm{OC}$, and $\mathrm{PM}_{2.5}$ are $-0.22,-0.15,-0.09$, $+0.08,+0.63$, and $+0.26 \mathrm{Tg}$, respectively, with the positive (or negative) values indicating northward (or southward) transport of aerosols. The signs of the aerosol fluxes are determined by the directions of winds and the simulated distributions of aerosols. In DJF and SON, while southward fluxes of all aerosol species are found in the lower troposphere over $100^{\circ}-125^{\circ} \mathrm{E}$ because of the prevailing northerlies over eastern China, northward fluxes of aerosols are found through the depth of the troposphere over $90^{\circ}-100^{\circ} \mathrm{E}$ and in the 
Table 4. Simulated inflow of aerosols to western China through the meridional plane along $75^{\circ} \mathrm{E}$ from $35^{\circ}$ to $55^{\circ} \mathrm{N}$. Numbers in the parentheses are percentage changes relative to the present-day fluxes. The units are $\mathrm{Tg}_{\mathrm{g} \text { season }}^{-1}$ for seasonal fluxes and $\mathrm{Tg}_{\mathrm{yr}}^{-1} \mathrm{for}^{\mathrm{annual}}$ fluxes of whole species (e.g., $\mathrm{Tg}\left(\mathrm{SO}_{4}^{2-}\right)$ season $\left.^{-1}, \mathrm{Tg}\left(\mathrm{SO}_{4}^{2-}\right) \mathrm{yr}^{-1}\right)$.

\begin{tabular}{|c|c|c|c|c|c|c|}
\hline \multirow[b]{2}{*}{ Species } & & \multicolumn{5}{|c|}{ Inflow to western China } \\
\hline & & $2000^{\mathrm{a}}(\mathrm{Tg})$ & $2050^{\mathrm{b}}(\mathrm{Tg})$ & $2050^{\mathrm{c}}(\mathrm{Tg})$ & $2050^{\mathrm{d}}(\mathrm{Tg})$ & NonL $^{\mathrm{e}}$ \\
\hline \multirow{5}{*}{$\mathrm{SO}_{4}^{2-}$} & DJF & 0.78 & $0.82(+5.1 \%)$ & $0.84(+7.7 \%)$ & $0.84(+7.7 \%)$ & 1.67 \\
\hline & MAM & 0.71 & $0.67(-5.6 \%)$ & $0.73(+2.8 \%)$ & $0.70(-1.4 \%)$ & 2.00 \\
\hline & JJA & 0.27 & $0.26(-3.7 \%)$ & $0.23(-14.8 \%)$ & $0.24(-11.1 \%)$ & 1.67 \\
\hline & SON & 0.53 & $0.52(-1.1 \%)$ & $0.53(+0.8 \%)$ & $0.53(+0.8 \%)$ & -0.50 \\
\hline & Annual & 2.29 & $2.27(-0.9 \%)$ & $2.32(+1.7 \%)$ & $2.31(+0.9 \%)$ & 1.00 \\
\hline \multirow{5}{*}{$\mathrm{NO}_{3}^{-}$} & DJF & 0.075 & $0.053(-29.3 \%)$ & $0.15(+100.0 \%)$ & $0.10(+33.3 \%)$ & 2.12 \\
\hline & MAM & 0.15 & $0.11(-26.7 \%)$ & $0.29(+93.3 \%)$ & $0.22(+46.7 \%)$ & 1.43 \\
\hline & JJA & 0.25 & $0.19(-24.0 \%)$ & $0.42(+68.0 \%)$ & $0.34(+36.0 \%)$ & 1.22 \\
\hline & SON & 0.11 & $0.088(-20.0 \%)$ & $0.27(+145.5 \%)$ & $0.22(+100.0 \%)$ & 1.25 \\
\hline & Annual & 0.59 & $0.44(-25.4 \%)$ & $1.13(+91.5 \%)$ & $0.88(+49.2 \%)$ & 1.34 \\
\hline \multirow{5}{*}{$\mathrm{NH}_{4}^{+}$} & DJF & 0.12 & $0.11(-8.3 \%)$ & $0.18(+50.0 \%)$ & $0.17(+41.7 \%)$ & 1.00 \\
\hline & MAM & 0.18 & $0.16(-11.1 \%)$ & $0.25(+38.9 \%)$ & $0.23(+27.8 \%)$ & 1.00 \\
\hline & JJA & 0.16 & $0.14(-12.5 \%)$ & $0.20(+25.0 \%)$ & $0.18(+12.5 \%)$ & 1.00 \\
\hline & SON & 0.15 & $0.13(-13.3 \%)$ & $0.22(+46.7 \%)$ & $0.20(+33.3 \%)$ & 1.00 \\
\hline & Annual & 0.61 & $0.54(-11.5 \%)$ & $0.85(+39.3 \%)$ & $0.79(+27.9 \%)$ & 1.00 \\
\hline \multirow{5}{*}{$\mathrm{BC}$} & DJF & 0.038 & $0.038(0.0 \%)$ & $0.030(-21.1 \%)$ & $0.030(-21.1 \%)$ & 1.00 \\
\hline & MAM & 0.045 & $0.043(-4.4 \%)$ & $0.037(-17.8 \%)$ & $0.034(-24.4 \%)$ & 0.91 \\
\hline & JJA & 0.023 & $0.022(-4.3 \%)$ & $0.016(-30.4 \%)$ & $0.015(-34.8 \%)$ & 1.00 \\
\hline & SON & 0.030 & $0.029(-3.3 \%)$ & $0.021(-30.0 \%)$ & $0.020(-33.3 \%)$ & 1.00 \\
\hline & Annual & 0.14 & $0.13(-7.1 \%)$ & $0.10(-28.6 \%)$ & $0.099(-29.3 \%)$ & 1.22 \\
\hline \multirow{5}{*}{$\mathrm{OC}$} & DJF & 0.077 & $0.077(0.0 \%)$ & $0.054(-29.9 \%)$ & $0.054(-29.9 \%)$ & 1.00 \\
\hline & MAM & 0.11 & $0.10(-9.1 \%)$ & $0.097(-11.8 \%)$ & $0.090(-18.2 \%)$ & 1.15 \\
\hline & JJA & 0.053 & $0.046(-13.2 \%)$ & $0.042(-20.8 \%)$ & $0.036(-32.1 \%)$ & 1.06 \\
\hline & SON & 0.056 & $0.052(-7.1 \%)$ & $0.037(-33.9 \%)$ & $0.033(-41.1 \%)$ & 1.00 \\
\hline & Annual & 0.30 & $0.28(-6.7 \%)$ & $0.23(-23.3 \%)$ & $0.21(-30.0 \%)$ & 1.00 \\
\hline \multirow{5}{*}{$\mathrm{PM}_{2.5}$} & DJF & 1.08 & $1.09(+0.9 \%)$ & $1.25(+15.7 \%)$ & $1.20(+11.1 \%)$ & 1.50 \\
\hline & MAM & 1.19 & $1.09(-8.4 \%)$ & $1.41(+18.5 \%)$ & $1.28(+7.6 \%)$ & 1.33 \\
\hline & JJA & 0.75 & $0.66(-12.0 \%)$ & $0.91(+21.3 \%)$ & $0.81(+8.0 \%)$ & 1.17 \\
\hline & SON & 0.87 & $0.82(-5.7 \%)$ & $1.08(+24.1 \%)$ & $1.01(+16.1 \%)$ & 1.14 \\
\hline & Annual & 3.89 & $3.66(-5.9 \%)$ & $4.65(+19.5 \%)$ & $4.30(+10.5 \%)$ & 1.29 \\
\hline
\end{tabular}

a Seasonal and annual total fluxes averaged over 1996-2005; ${ }^{b}$ year 2050 fluxes simulated with climate change alone; ${ }^{c}$ year 2050 fluxes simulated with changes in anthropogenic emissions alone; ${ }^{\mathrm{d}}$ year 2050 fluxes simulated with changes in both climate and anthropogenic emissions; ${ }^{\mathrm{e}}$ NonL $=\frac{\left(2050^{\mathrm{b}}-2000^{\mathrm{a}}\right)+\left(2050^{\mathrm{c}}-2000^{\mathrm{a}}\right)}{2050^{\mathrm{d}}-2000^{\mathrm{a}}}$.

upper troposphere over $100^{\circ}-125^{\circ} \mathrm{E}$ (Fig. 13). In MAM and JJA, the southerlies associated with the summer monsoon generally favor northward transport (Fig. 13). The fluxes of aerosols across the southern boundary of China are generally much smaller than those through the eastern and western boundaries. One exception is that the fluxes of BC and OC to China in MAM are amplified as a result of the predominant biomass burning in South Asia in this season (Zhang et al., 2010b).

\subsubsection{Effect of changes in climate alone}

As a result of the future climate change alone, the changes in annual fluxes of aerosol species are generally small except that the annual southward flux of $\mathrm{NO}_{3}^{-}$is simulated to increase by $26.7 \%$ relative to the present-day value. The percentage changes in seasonal fluxes are usually much larger. In DJF, the northerlies in the lower troposphere east of $100^{\circ} \mathrm{E}$ are predicted to be stronger and the southerlies west of $100^{\circ} \mathrm{E}$ become weaker (Fig. 13), which lead to increases in transport of $\mathrm{SO}_{4}^{2-}, \mathrm{NO}_{3}^{-}$, and $\mathrm{PM}_{2.5}$ from China to South Asia by $33 \%, 11 \%$, and $67 \%$, respectively. In JJA, the southerlies associated with the summer monsoon are simulated to strengthen in the future climate and hence favor the northward transport of aerosols. The fluxes of all aerosol species to South Asia show reductions in SON, which can be explained by the weaker northerlies in the future atmosphere (Fig. 13). 
( a )
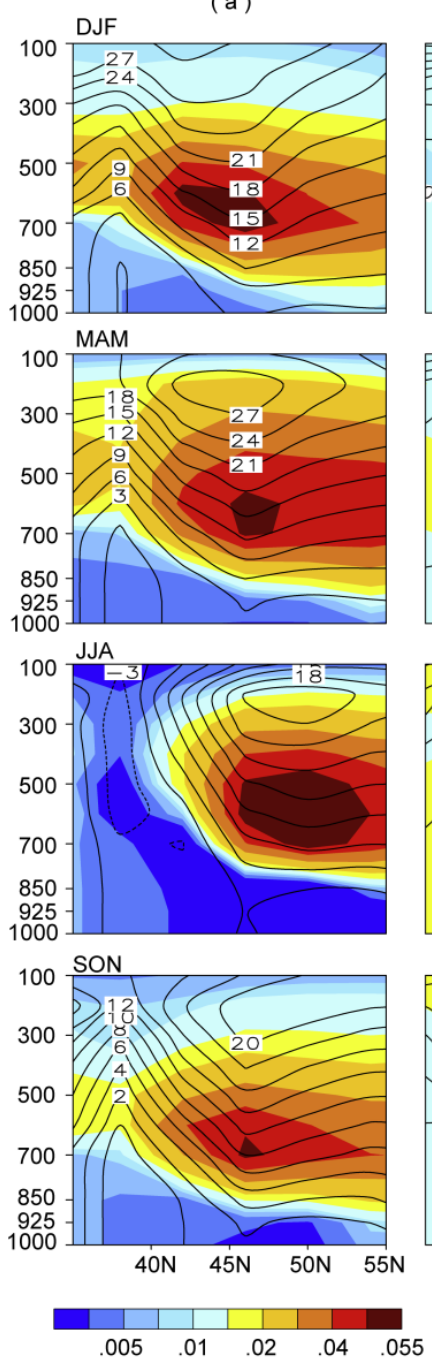

(b)
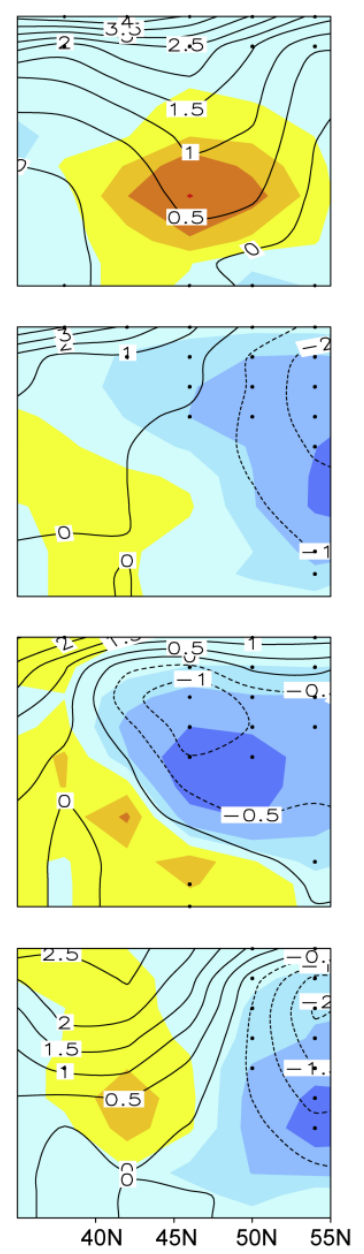

(c)
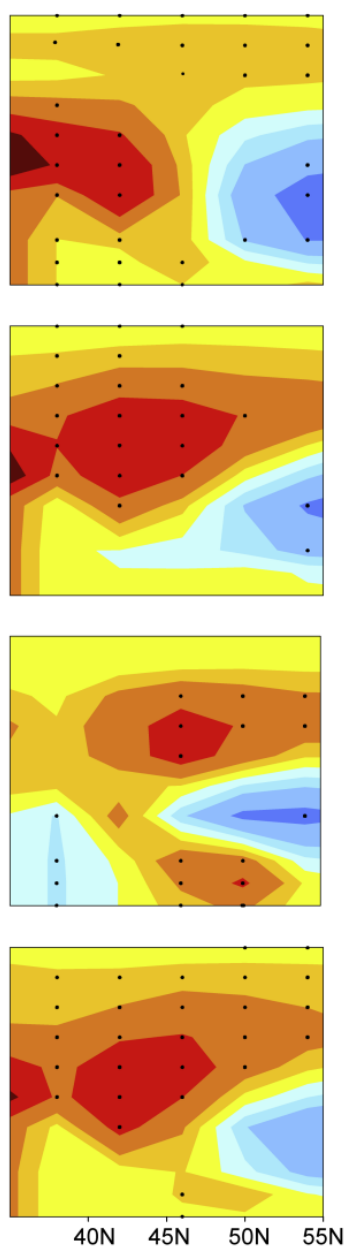

(d)
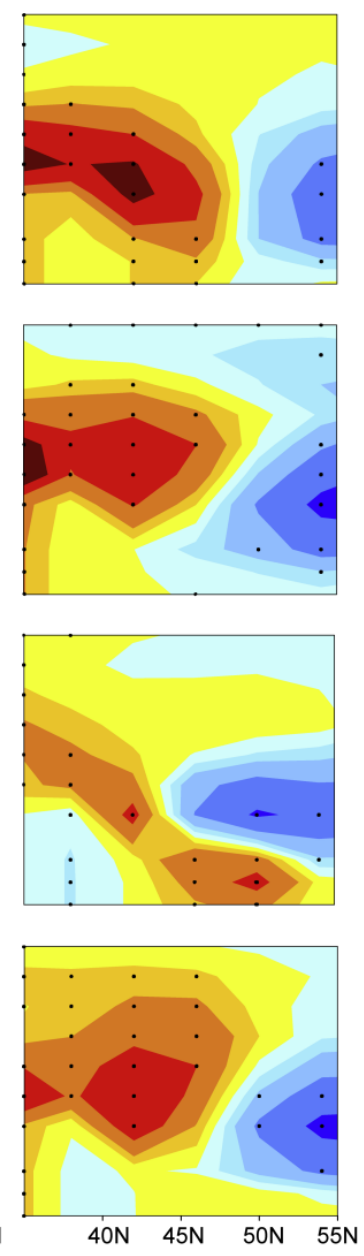

$15 \quad .02$

Fig. 12. Same as Fig. 11 but mass fluxes and winds are those through the meridional plane along $75^{\circ} \mathrm{E}$ from $35^{\circ}$ to $55^{\circ} \mathrm{N}$.

\subsubsection{Effect of changes in anthropogenic emissions alone}

The annual fluxes of $\mathrm{SO}_{4}^{2-}$ and $\mathrm{NH}_{4}^{+}$are simulated to change from a net southward outflow to a net northward inflow, as a result of the changes in anthropogenic emissions over 20002050 (Table 5). The annual southward flux of $\mathrm{NO}_{3}^{-}$increases by $60 \%$, and the annual northward fluxes of BC, OC, and $\mathrm{PM}_{2.5}$ increase by $48 \%, 14 \%$, and $281 \%$, respectively. The annual fluxes of $\mathrm{SO}_{4}^{2-}$ and $\mathrm{NH}_{4}^{+}$exhibit large increases in northward transport because of the large increases in aerosol concentrations in South Asia and Southeast Asia (Fig. 8), and the annual inflow of $\mathrm{BC}$ and $\mathrm{OC}$ also increases because the reductions in carbonaceous aerosol concentrations in eastern China are projected to be larger than those in South Asia and Southeast Asia (Fig. 8). In contrast, the annual flux of $\mathrm{NO}_{3}^{-}$ exhibits southward outflow because of the large increases in $\mathrm{NO}_{3}^{-}$levels in eastern China (Fig. 8).

\subsubsection{Effect of changes in both climate and anthropogenic emissions}

Simulated fluxes of aerosols through the latitudinal plane along $21.7^{\circ} \mathrm{N}$ from $90^{\circ}$ to $125^{\circ} \mathrm{E}$ with the future changes in both anthropogenic emissions and climate are listed in Table 5. The year 2050 annual fluxes of $\mathrm{SO}_{4}^{2-}, \mathrm{NH}_{4}^{+}, \mathrm{BC}, \mathrm{OC}$, and $\mathrm{PM}_{2.5}$ are simulated as northward into China, and the annual flux of $\mathrm{NO}_{3}^{-}$is southward out of China. The 20002050 changes in fluxes of all aerosol species are dominated by the contributions from changes in anthropogenic emissions. However, the role of future climate change can exceed that of future changes in emissions for the fluxes of $\mathrm{NO}_{3}^{-}$in DJF, BC in JJA, as well as OC in DJF (Table 5). 
( a )
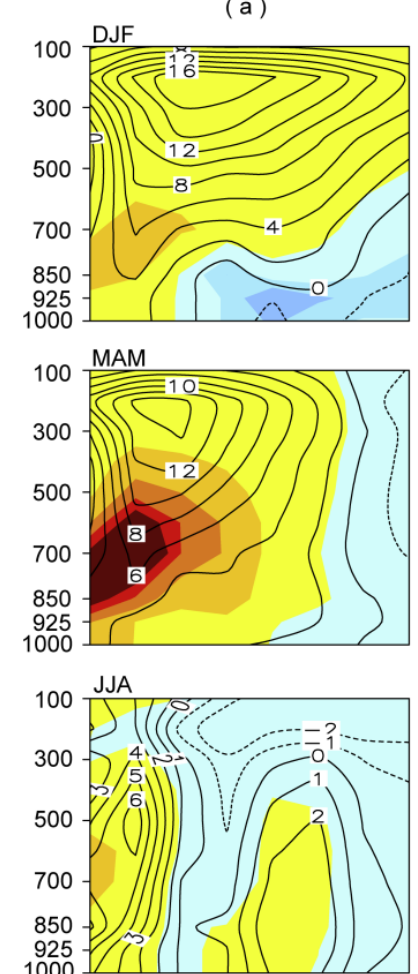

1000

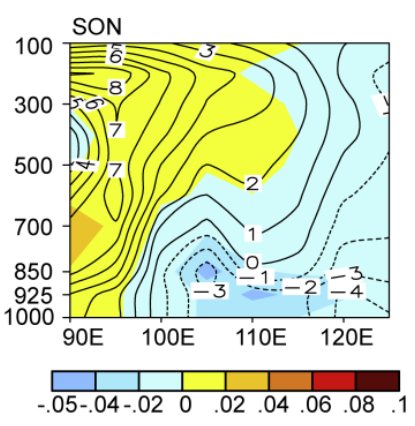

( b )
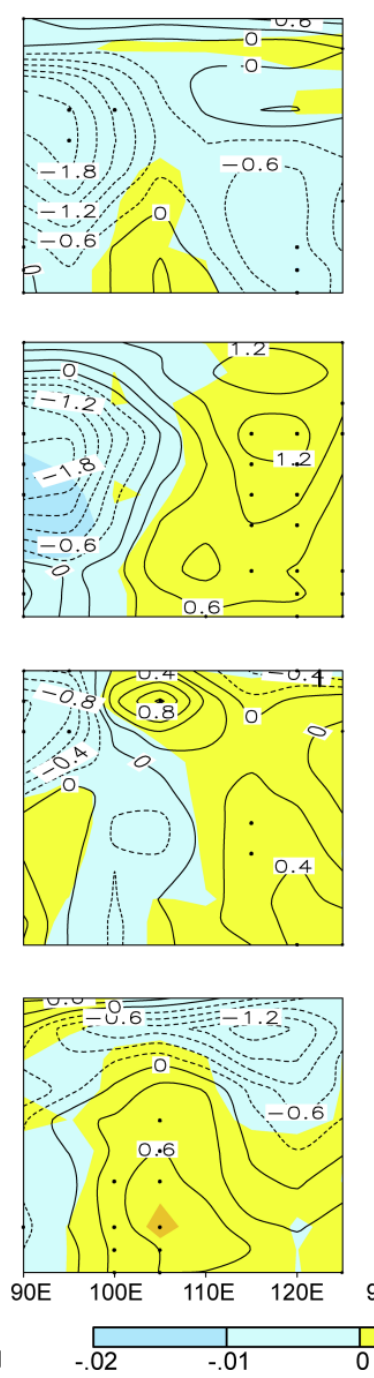

(c)
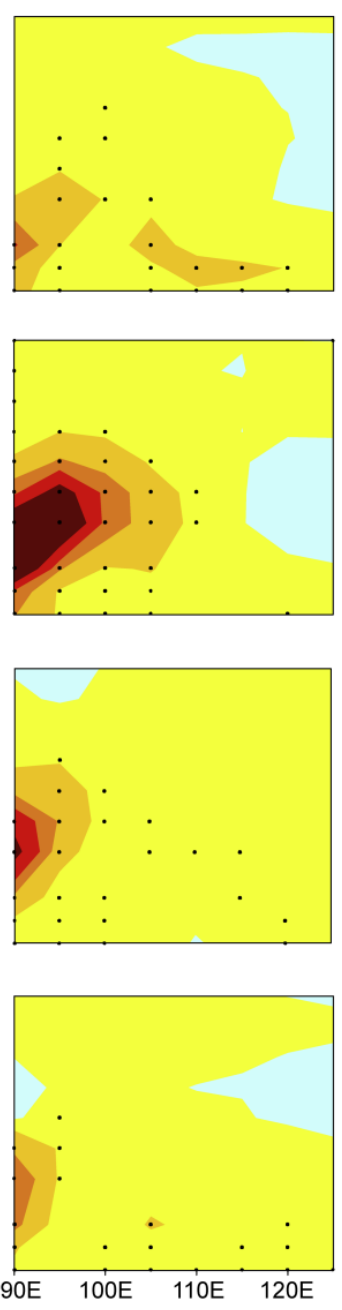

(d)
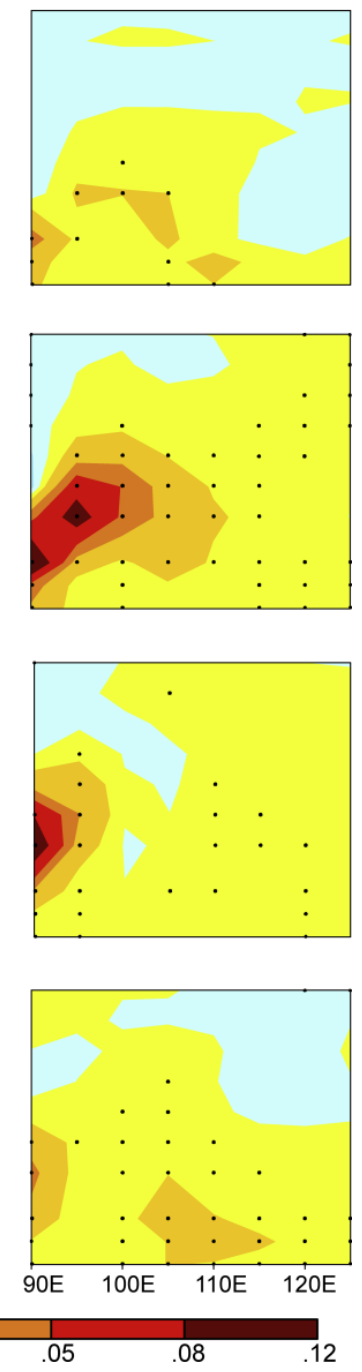

Fig. 13. (a) Simulated present-day mass fluxes of $\mathrm{PM}_{2.5}$ and meridional winds. Projected changes in mass fluxes of $\mathrm{PM}_{2.5}$ and meridional winds from the present day (1996-2005) to future (2046-2055) owing to (b) climate change alone, (c) changes in anthropogenic emissions alone, and (d) changes in both climate and anthropogenic emissions. Mass fluxes of $\mathrm{PM}_{2.5}$ are shown by shades (units: $\mathrm{Tg}$ ), and winds are represented by contours (units: $\mathrm{m} \mathrm{s}^{-1}$ ). Both mass fluxes and winds are those through latitudinal plane along $21.7^{\circ} \mathrm{N}$ from $90^{\circ}$ to $125^{\circ}$ E. Positive (negative) fluxes indicate northward (southward) transport. The dotted areas are statistically significant at the $95 \%$ level, as determined by Student's two-sample $t$ test.

\section{Conclusions}

We estimate changes in aerosol levels in China and the transboundary transport of aerosols in and out of China over the period 2000-2050 by using the global chemical transport model GEOS-Chem with meteorological input from the general circulation model GISS GCM 3 (at $4^{\circ} \times 5^{\circ}$ resolution) and changes in emissions based on the IPCC A1B scenario.

The projected 2000-2050 change in climate alone is estimated to lead to changes in seasonal mean concentrations of individual aerosol species at $4^{\circ} \times 5^{\circ}$ resolution over China ranging from -1.5 to $+0.8 \mu \mathrm{g} \mathrm{m}^{-3}$. As a result of these changes in individual aerosol species, future $\mathrm{PM}_{2.5}$ concentrations in China are simulated to decrease generally, except that increases are predicted along east and southeast coasts of China in DJF and over a large fraction of eastern China in MAM. The simulated climate-induced changes in $\mathrm{PM}_{2.5}$ concentrations in China are within $\pm 2.5 \mu \mathrm{g} \mathrm{m}^{-3}$, which represent about $10-20 \%$ of the present-day concentrations in those regions.

As a result of the future changes in anthropogenic emissions alone, concentrations of sulfate, $\mathrm{BC}$, and $\mathrm{OC}$ are simulated to decrease by $0.5-3.5 \mu \mathrm{g} \mathrm{m}^{-3}, 0.5-2 \mu \mathrm{g} \mathrm{m}^{-3}$, and $0.5-$ $3.5 \mu \mathrm{g} \mathrm{m}^{-3}$, respectively, in eastern China. On the contrary, 
Table 5. Simulated transport of aerosols to or from southern China through the latitudinal plane along $21.7^{\circ} \mathrm{N}$ from $90^{\circ}$ to $125^{\circ} \mathrm{E}$. Positive (negative) values indicate northward (southward) transport. Percentage change is listed in the parentheses as the 2050 flux has the same sign as 2000 flux. The units are $\mathrm{Tg}_{\mathrm{g}}$ season ${ }^{-1}$ for seasonal fluxes and $\mathrm{Tg} \mathrm{yr}^{-1}$ for annual fluxes of whole $\operatorname{species}\left(\mathrm{e} . \mathrm{g}\right.$., $\mathrm{Tg}\left(\mathrm{SO}_{4}^{2-}\right) \mathrm{season}^{-1}$, $\left.\mathrm{Tg}\left(\mathrm{SO}_{4}^{2-}\right) \mathrm{yr}^{-1}\right)$.

\begin{tabular}{|c|c|c|c|c|c|c|}
\hline \multirow[b]{2}{*}{ Species } & & \multicolumn{5}{|c|}{ Transport to or from southern China } \\
\hline & & $2000^{\mathrm{a}}(\mathrm{Tg})$ & $2050^{\mathrm{b}}(\mathrm{Tg})$ & $2050^{\mathrm{c}}(\mathrm{Tg})$ & $2050^{\mathrm{d}}(\mathrm{Tg})$ & $\operatorname{NonL}^{\mathrm{e}}$ \\
\hline \multirow{5}{*}{$\mathrm{SO}_{4}^{2-}$} & DJF & -0.11 & $-0.15(+33.4 \%)$ & $-0.0094(-91.5 \%)$ & $-0.047(-57.3 \%)$ & 0.96 \\
\hline & MAM & 0.088 & $0.11(+25.0 \%)$ & $0.41(+365.9 \%)$ & $0.43(+388.6 \%)$ & 1.01 \\
\hline & JJA & -0.011 & $-0.0051(-53.6 \%)$ & $0.023(-)$ & $0.047(-)$ & 0.69 \\
\hline & SON & -0.19 & $-0.16(-15.8 \%)$ & $-0.13(-31.6 \%)$ & $-0.11(-42.1 \%)$ & 1.13 \\
\hline & Annual & -0.22 & $-0.21(-4.5 \%)$ & $0.29(-)$ & $0.32(-)$ & 0.96 \\
\hline \multirow{5}{*}{$\mathrm{NO}_{3}^{-}$} & DJF & -0.047 & $-0.052(+10.6 \%)$ & $-0.050(+6.4 \%)$ & $-0.059(+25.5 \%)$ & 0.67 \\
\hline & MAM & 0.10 & $0.045(-55.0 \%)$ & $0.19(+90.0 \%)$ & $0.045(-55.0 \%)$ & -0.64 \\
\hline & JJA & -0.12 & $-0.11(-8.3 \%)$ & $-0.31(+158.3 \%)$ & $-0.29(+141.7 \%)$ & 1.06 \\
\hline & SON & -0.086 & $-0.069(-19.8 \%)$ & $-0.069(-19.8 \%)$ & $-0.050(-41.9 \%)$ & 0.94 \\
\hline & Annual & -0.15 & $-0.19(+26.7 \%)$ & $-0.24(+60.0 \%)$ & $-0.35(+133.3 \%)$ & 0.65 \\
\hline \multirow{5}{*}{$\mathrm{NH}_{4}^{+}$} & DJF & -0.043 & $-0.054(+25.6 \%)$ & $-0.0035(-91.9 \%)$ & $-0.017(-60.5 \%)$ & 1.10 \\
\hline & MAM & 0.066 & $0.055(-16.7 \%)$ & $0.22(+233.3 \%)$ & $0.18(+172.7 \%)$ & 1.25 \\
\hline & JJA & -0.035 & $-0.029(-17.1 \%)$ & $-0.085(+142.9 \%)$ & $-0.070(+100.0 \%)$ & 1.26 \\
\hline & SON & -0.073 & $-0.058(-20.5 \%)$ & $-0.047(-35.6 \%)$ & $-0.039(-46.6 \%)$ & 1.21 \\
\hline & Annual & -0.085 & $-0.086(+1.2 \%)$ & $0.085(-)$ & $0.054(-)$ & 1.22 \\
\hline \multirow{5}{*}{$\mathrm{BC}$} & DJF & -0.00088 & $-0.0054(+513.6 \%)$ & $0.013(-)$ & $0.0097(-)$ & 0.88 \\
\hline & MAM & 0.095 & $0.097(+2.1 \%)$ & $0.11(+15.8 \%)$ & $0.11(+15.8 \%)$ & 1.13 \\
\hline & JJA & 0.0029 & $0.0043(+48.3 \%)$ & $0.0039(+34.5 \%)$ & $0.0050(+72.4 \%)$ & 1.14 \\
\hline & SON & -0.016 & $-0.012(-25.0 \%)$ & $-0.0033(-79.4 \%)$ & $-0.0017(-89.4 \%)$ & 1.17 \\
\hline & Annual & 0.081 & $0.084(+3.7 \%)$ & $0.12(+48.1 \%)$ & $0.12(+48.1 \%)$ & 1.08 \\
\hline \multirow{5}{*}{$\mathrm{OC}$} & DJF & 0.076 & $0.057(-25.0 \%)$ & $0.090(+18.4 \%)$ & $0.074(-2.6 \%)$ & 2.50 \\
\hline & MAM & 0.56 & $0.56(0.0 \%)$ & $0.63(+12.5 \%)$ & $0.63(+12.5 \%)$ & 1.00 \\
\hline & JJA & 0.017 & $0.022(+29.4 \%)$ & $0.0083(-51.2 \%)$ & $0.011(-35.3 \%)$ & 0.62 \\
\hline & SON & -0.020 & $-0.012(-40.0 \%)$ & $-0.0075(-62.5 \%)$ & $-0.0046(-77.0 \%)$ & 1.33 \\
\hline & Annual & 0.63 & $0.63(0.0 \%)$ & $0.72(+14.3 \%)$ & $0.71(+12.7 \%)$ & 1.13 \\
\hline \multirow{5}{*}{$\mathrm{PM}_{2.5}$} & $\mathrm{DJF}$ & -0.12 & $-0.20(+66.7 \%)$ & $0.040(-)$ & $-0.040(-66.7 \%)$ & 1.00 \\
\hline & MAM & 0.91 & $0.87(-4.4 \%)$ & $1.57(+72.5 \%)$ & $1.40(+53.8 \%)$ & 1.27 \\
\hline & JJA & -0.14 & $-0.12(-14.3 \%)$ & $-0.36(+157.1 \%)$ & $-0.30(+114.3 \%)$ & 1.25 \\
\hline & SON & -0.39 & $-0.31(-20.5 \%)$ & $-0.26(-33.0 \%)$ & $-0.21(-46.2 \%)$ & 1.17 \\
\hline & Annual & 0.26 & $0.24(-7.7 \%)$ & $0.99(+280.8 \%)$ & $0.85(+226.9 \%)$ & 1.20 \\
\hline
\end{tabular}

a Seasonal and annual total fluxes averaged over 1996-2005; ${ }^{b}$ year 2050 fluxes simulated with climate change alone; ${ }^{c}$ year 2050 fluxes simulated with changes in anthropogenic emissions alone; ${ }^{\mathrm{d}}$ year 2050 fluxes simulated with changes in both climate and anthropogenic emissions; ${ }^{\mathrm{e}}$ NonL $=\frac{\left(2050^{\mathrm{b}}-2000^{\mathrm{a}}\right)+\left(2050^{\mathrm{c}}-2000^{\mathrm{a}}\right)}{2050^{\mathrm{d}}-2000^{\mathrm{a}}}$

nitrate concentrations are predicted to increase in eastern China over 2000-2050, with the largest increases of 1$2 \mu \mathrm{g} \mathrm{m}^{-3}$ in DJF, 3.5-4.5 $\mathrm{g} \mathrm{m}^{-3}$ in JJA, and $2-3.5 \mu \mathrm{g} \mathrm{m}^{-3}$ in MAM and SON. The projected changes in $\mathrm{PM}_{2.5}$ owing to the changes in emissions alone show decreases in $\mathrm{PM}_{2.5}$ concentrations of $1-8 \mathrm{\mu g} \mathrm{m}^{-3}$ in eastern China over 2000-2050 at a $4^{\circ} \times 5^{\circ}$ resolution. Under the IPCC A1B scenario, future changes in anthropogenic emissions exert a larger effect on year $2050 \mathrm{PM}_{2.5}$ concentrations in eastern China than does projected future climate change.

The estimated year 2050 transboundary fluxes of aerosol species to and from China are sensitive to future changes in climate and emissions. The present-day flux of $\mathrm{PM}_{2.5}$ from eastern China to the western Pacific (through the meridional plane along $135^{\circ} \mathrm{E}$ from $20^{\circ}$ to $55^{\circ} \mathrm{N}$ ) is simulated to be $10.8 \mathrm{Tg} \mathrm{yr}^{-1}$, and the annual outflow of $\mathrm{PM}_{2.5}$ is estimated to change by $-7.0 \%,-0.7 \%$, and $-9.0 \%$, respectively, over 2000-2050 owing to future climate change alone, future changes in emissions alone, and future changes in both climate emissions. Climate change is predicted to have a larger impact on future fluxes of aerosols than changes in emissions. While annual fluxes of all aerosol species show reductions by climate change alone, future increases in outflow of nitrate and ammonium offset to a large extent the future decreases in outflow of sulfate, $\mathrm{BC}$, and $\mathrm{OC}$, leading to a small 
negative change in annual outflow of $\mathrm{PM}_{2.5}$ as a result of changes in emissions alone.

The present-day inflow of $\mathrm{PM}_{2.5}$ aerosols from Europe and Central Asia to western China (the fluxes through the meridional plane along $75^{\circ} \mathrm{E}$ from $35^{\circ}$ to $55^{\circ} \mathrm{N}$ ) is calculated to be $3.9 \mathrm{Tg} \mathrm{yr}^{-1}$. Over $2000-2050$, the fluxes of nitrate and ammonium aerosols are estimated to increase largely as a result of future changes in emissions, leading to an overall $10.5 \%$ estimated increase in annual inflow of $\mathrm{PM}_{2.5}$ to western China as a result of future changes in both emissions and climate.

The present-day net transport of $\mathrm{PM}_{2.5}$ aerosols across the southern boundary (the latitudinal plane along $21.7^{\circ} \mathrm{N}$ from $90^{\circ}$ to $125^{\circ} \mathrm{E}$ ) is estimated as $0.26 \mathrm{Tg} \mathrm{yr}^{-1}$, in which the fluxes of sulfate, nitrate, and ammonium are southward out of China and those of $\mathrm{BC}$ and $\mathrm{OC}$ are northward into China. Fluxes of $\mathrm{BC}$ and $\mathrm{OC}$ to China in MAM contribute to a large fraction of the annual inflow of $\mathrm{PM}_{2.5}$, as a result of biomass burning in South Asia in this season. The annual net inflow of $\mathrm{PM}_{2.5}$ across the southern boundary of China is estimated to change by $-8 \%,+281 \%$, and $+227 \%$ over $2000-2050$ owing to climate change alone, changes in emissions alone, and changes in both climate and emissions, respectively.

Results from the present study indicate that climate change is important for domestic air quality in China as well as longrange transport of aerosols.

\section{Supplementary material related to this article is available online at: http://www.atmos-chem-phys.net/13/ 7937/2013/acp-13-7937-2013-supplement.pdf.}

Acknowledgements. This work was supported by the Chinese Academy of Sciences Strategic Priority Research Program Grant No. XDA05100503, the National Natural Science Foundation of China under grants 40775083, 40825016, and 41021004, as well as the China Meteorological Administration special funding in atmospheric science GYHY200906020. S. Wu acknowledges support from the US EPA STAR program (grant \# 83428601). The US Environmental Protection Agency through its Office of Research and Development collaborated in the research described here. It has been subjected to the US Environmental Protection Agency's administrative review and has been approved for publication.

Edited by: X. H. Liu

\section{References}

Alexander, B., Park, R. J., Jacob, D. J., Li, Q. B., Yantosca, R. M., Savarino, J., Lee, C. C. W., and Thiemens, M. H.: Sulfate formation in sea-salt aerosols: constraints from oxygen isotopes, J. Geophys. Res.-Atmos., 110, D10307, doi:10.1029/2004jd005659, 2005.

Andersson, C. and Engardt, M.: European ozone in a future climate: importance of changes in dry deposition and isoprene emissions, J. Geophys. Res.-Atmos., 115, D02303, doi:10.1029/2008jd011690, 2010.
Avise, J., Chen, J., Lamb, B., Wiedinmyer, C., Guenther, A., Salathé, E., and Mass, C.: Attribution of projected changes in summertime US ozone and $\mathrm{PM}_{2.5}$ concentrations to global changes, Atmos. Chem. Phys., 9, 1111-1124, doi:10.5194/acp9-1111-2009, 2009.

Bauer, S. E., Koch, D., Unger, N., Metzger, S. M., Shindell, D. T., and Streets, D. G.: Nitrate aerosols today and in 2030: a global simulation including aerosols and tropospheric ozone, Atmos. Chem. Phys., 7, 5043-5059, doi:10.5194/acp-7-5043-2007, 2007.

Bey, I., Jacob, D. J., Yantosca, R. M., Logan, J. A., Field, B. D., Fiore, A. M., Li, Q. B., Liu, H. G. Y., Mickley, L. J., and Schultz, M. G.: Global modeling of tropospheric chemistry with assimilated meteorology: model description and evaluation, J. Geophys. Res.-Atmos., 106, 23073-23095, doi: 10.1029/2001JD000807, 2001.

Cao, J. J., Shen, Z.-X., Chow, J. C., Watson, J. G., Lee, S.-C., Tie, X.-X., Ho, K.-F., Wang, G.-H., and Han, Y.-M.: Winter and summer $\mathrm{PM}_{2.5}$ chemical compositions in fourteen Chinese cities, J. Air Waste Manage. Assoc., 62, 1214-1226, doi: 10.1080/10962247.2012.701193, 2012.

Chan, C. K. and Yao, X.: Air pollution in mega cities in China, Atmos. Environ., 42, 1-42, doi:10.1016/j.atmosenv.2007.09.003, 2008.

Chang, H. H., Zhou, J. W., and Fuentes, M.: Impact of climate change on ambient ozone level and mortality in southeastern United States, Int. J. Env. Res. Pub. He., 7, 2866-2880, doi:10.3390/ijerph7072866, 2010.

Chin, Mian, Diehl, T., Ginoux, P., and Malm, W.: Intercontinental transport of pollution and dust aerosols: implications for regional air quality, Atmos. Chem. Phys., 7, 5501-5517, doi:10.5194/acp7-5501-2007, 2007.

Clarke, A. D., Collins, W. G., Rasch, P. J., Kapustin, V. N., Moore, K., Howell, S., and Fuelberg, H. E.: Dust and pollution transport on global scales: aerosol measurements and model predictions, J. Geophys. Res.-Atmos., 106, 32555-32569, doi:10.1029/2000jd900842, 2001.

Day, M. C. and Pandis, S. N.: Predicted changes in summertime organic aerosol concentrations due to increased temperatures, Atmos. Environ., 45, 6546-6556, doi:10.1016/j.atmosenv.2011.08.028, 2011.

Fairlie, T. D., Jacob, D. J., and Park, R. J.: The impact of transpacific transport of mineral dust in the United States, Atmos. Environ., 41, 1251-1266, doi:10.1016/j.atmosenv.2006.09.048, 2007.

Fu, T.-M., Cao, J. J., Zhang, X. Y., Lee, S. C., Zhang, Q., Han, Y. M., Qu, W. J., Han, Z., Zhang, R., Wang, Y. X., Chen, D., and Henze, D. K.: Carbonaceous aerosols in China: top-down constraints on primary sources and estimation of secondary contribution, Atmos. Chem. Phys., 12, 2725-2746, doi:10.5194/acp12-2725-2012, 2012.

Guenther, A., Hewitt, C. N., Erickson, D., Fall, R., Geron, C., Graedel, T., Harley, P., Klinger, L., Lerdau, M., Mckay, W. A., Pierce, T., Scholes, B., Steinbrecher, R., Tallamraju, R., Taylor, J., and Zimmerman, P.: A global-model of natural volatile organic-compound emissions, J. Geophys. Res.-Atmos., 100, 8873-8892, 1995.

Heald, C. L., Jacob, D. J., Park, R. J., Alexander, B., Fairlie, T. D., Yantosca, R. M., and Chu, D. A.: Transpacific transport of Asian anthropogenic aerosols and its impact on surface air qual- 
ity in the United States, J. Geophys. Res.-Atmos., 111, D14310, doi:10.1029/2005jd006847, 2006.

Henze, D. K. and Seinfeld, J. H.: Global secondary organic aerosol from isoprene oxidation, Geophys. Res. Lett., 33, L09812, doi:10.1029/2006gl025976, 2006.

Henze, D. K., Seinfeld, J. H., Ng, N. L., Kroll, J. H., Fu, T.M., Jacob, D. J., and Heald, C. L.: Global modeling of secondary organic aerosol formation from aromatic hydrocarbons: highvs. low-yield pathways, Atmos. Chem. Phys., 8, 2405-2420, doi:10.5194/acp-8-2405-2008, 2008.

Hogrefe, C., Lynn, B., Civerolo, K., Ku, J. Y., Rosenthal, J., Rosenzweig, C., Goldberg, R., Gaffin, S., Knowlton, K., and Kinney, P. L.: Simulating changes in regional air pollution over the eastern United States due to changes in global and regional climate and emissions, J. Geophys. Res.-Atmos., 109, D22301, doi:10.1029/2004jd004690, 2004.

Holzer, M., Hall, T. M., and Stull, R. B.: Seasonality and weatherdriven variability of transpacific transport, J. Geophys. Res.Atmos., 110, D23103, doi:10.1029/2005jd006261, 2005.

Huebert, B. J., Phillips, C. A., Zhuang, L., Kjellstrom, E., Rodhe, H., Feichter, J., and Land, C.: Long-term measurements of freetropospheric sulfate at Mauna Loa: comparison with global model simulations, J. Geophys. Res.-Atmos., 106, 5479-5492, doi:10.1029/2000jd900627, 2001.

Intergovernmental Panel for Climate Change (IPCC): Climate Change 2007: The Physical Science Basis, edited by Solomon, S., Qin, D., Manning, M., Chen, Z., Marquis, M., Averyt, K. B., Tignor, M., and Miller, H. L., Cambridge Univ. Press, Cambridge, UK, 2007.

Jacob, D. J. and Winner, D. A.: Effect of climate change on air quality, Atmos. Environ., 43, 51-63, doi:10.1016/j.atmosenv.2008.09.051, 2009.

Jordan, C. E., Dibb, J. E., Anderson, B. E., and Fuelberg, H. E.: Uptake of nitrate and sulfate on dust aerosols during TRACE-P, J. Geophys. Res.-Atmos., 108, 8817, doi:10.1029/2002jd003101, 2003.

Juda-Rezler, K., Reizer, M., Huszar, P., Krüger, B. C., Zanis, P., Syrakov, D., Katragkou, E., Trapp, W., Melas, D., Chervenkov, H., Tegoulias, I., and Halenka, T.: Modelling the effects of climate change on air quality over Central and Eastern Europe: concept, evaluation and projections, Clim. Res., 53, 179-203, doi:10.3354/cr01072, 2012.

Katragkou, E., Zanis, P., Kioutsioukis, I., Tegoulias, I., Melas, D., Krüger, B. C., and Coppola, E.: Future climate change impacts on summer surface ozone from regional climate-air quality simulations over Europe, J. Geophys. Res.-Atmos., 116, D22307, doi:10.1029/2011jd015899, 2011.

Koch, D., Schulz, M., Kinne, S., McNaughton, C., Spackman, J. R., Balkanski, Y., Bauer, S., Berntsen, T., Bond, T. C., Boucher, O., Chin, M., Clarke, A., De Luca, N., Dentener, F., Diehl, T., Dubovik, O., Easter, R., Fahey, D. W., Feichter, J., Fillmore, D., Freitag, S., Ghan, S., Ginoux, P., Gong, S., Horowitz, L., Iversen, T., Kirkevåg, A., Klimont, Z., Kondo, Y., Krol, M., Liu, X., Miller, R., Montanaro, V., Moteki, N., Myhre, G., Penner, J. E., Perlwitz, J., Pitari, G., Reddy, S., Sahu, L., Sakamoto, H., Schuster, G., Schwarz, J. P., Seland, Ø., Stier, P., Takegawa, N., Takemura, T., Textor, C., van Aardenne, J. A., and Zhao, Y.: Evaluation of black carbon estimations in global aerosol models, Atmos. Chem. Phys., 9, 9001-9026, doi:10.5194/acp-9-9001-2009,
2009.

Lam, Y. F., Fu, J. S., Wu, S., and Mickley, L. J.: Impacts of future climate change and effects of biogenic emissions on surface ozone and particulate matter concentrations in the United States, Atmos. Chem. Phys., 11, 4789-4806, doi:10.5194/acp-11-47892011, 2011.

Langner, J., Engardt, M., Baklanov, A., Christensen, J. H., Gauss, M., Geels, C., Hedegaard, G. B., Nuterman, R., Simpson, D., Soares, J., Sofiev, M., Wind, P., and Zakey, A.: A multi-model study of impacts of climate change on surface ozone in Europe, Atmos. Chem. Phys., 12, 10423-10440, doi:10.5194/acp12-10423-2012, 2012.

Liao, H., Chen, W.-T., and Seinfeld, J. H.: Role of climate change in global predictions of future tropospheric ozone and aerosols, $\mathrm{J}$ Geophys. Res., 111, D12304, doi:10.1029/2005jd006852, 2006.

Liao, H., Henze, D. K., Seinfeld, J. H., Wu, S. L., and Mickley, L. J.: Biogenic secondary organic aerosol over the United States: comparison of climatological simulations with observations, J. Geophys. Res.-Atmos., 112, D06201, doi:10.1029/2006jd007813, 2007.

Matsui, H., Koike, M., Kondo, Y., Takegawa, N., Kita, K., Miyazaki, Y., Hu, M., Chang, S. Y., Blake, D. R., Fast, J. D., Zaveri, R. A., Streets, D. G., Zhang, Q., and Zhu, T.: Spatial and temporal variations of aerosols around Beijing in summer 2006: model evaluation and source apportionment, J. Geophys. Res.Atmos., 114, D00g13, doi:10.1029/2008jd010906, 2009.

Maxwell-Meier, K., Weber, R., Song, C., Orsini, D., Ma, Y., Carmichael, G. R., and Streets, D. G.: Inorganic composition of fine particles in mixed mineral dust-pollution plumes observed from airborne measurements during ACE-Asia, J. Geophys. Res.-Atmos., 109, D19s07, doi:10.1029/2003jd004464, 2004.

Murazaki, K. and Hess, P.: How does climate change contribute to surface ozone change over the United States?, J. Geophys. Res.Atmos., 111, D05301, doi:10.1029/2005jd005873, 2006.

Nakicenovic, N. and Swart, R. (Eds.): Special Report on Emissions Scenarios, Cambridge Univ. Press, New York, 570 pp., 2000.

Park, R. J., Jacob, D. J., Chin, M., and Martin, R. V.: Sources of carbonaceous aerosols over the United States and implications for natural visibility, J. Geophys. Res.-Atmos., 108, 4355, doi:10.1029/2002jd003190, 2003.

Park, R. J., Jacob, D. J., Field, B. D., and Yantosca, R. M.: Natural and transboundary pollution influences on sulfatenitrate-ammonium aerosols in the United States: Implications for policy, J. Geophys. Res-Atmos., 109, D15204, doi:10.1029/2003jd004473, 2004.

Price, C. and Rind, D.: A simple lightning parameterization for calculating global lightning distributions, J. Geophys. Res.-Atmos., 97, 9919-9933, doi:10.1029/92JD00719, 1992.

Price, H. U., Jaffe, D. A., Doskey, P. V., McKendry, I., and Anderson, T. L.: Vertical profiles of $\mathrm{O}_{3}$, aerosols, $\mathrm{CO}$ and NMHCs in the Northeast Pacific during the TRACE-P and ACE-ASIA experiments, J. Geophys. Res.-Atmos., 108, 8799, doi:10.1029/2002jd002930, 2003.

Prospero, J. M., Savoie, D. L., and Arimoto, R.: Long-term record of nss-sulfate and nitrate in aerosols on Midway Island, 19812000: evidence of increased (now decreasing?) anthropogenic emissions from Asia, J. Geophys. Res.-Atmos., 108, 4019, doi:10.1029/2001jd001524, 2003. 
Pye, H. O. T., Liao, H.,Wu, S., Mickley, L. J., Jacob, D. J., Henze, D. K., and Seinfeld, J. H.: Effect of changes in climate and emissions on future sulfate-nitrate-ammonium aerosol levels in the United States, J. Geophys. Res.-Atmos., 114, D01205, doi:10.1029/2008jd010701, 2009.

Qu, W. J., Arimoto, R., Zhang, X. Y., Zhao, C. H., Wang, Y. Q., Sheng, L. F., and Fu, G.: Spatial distribution and interannual variation of surface $\mathrm{PM}_{10}$ concentrations over eighty-six Chinese cities, Atmos. Chem. Phys., 10, 5641-5662, doi:10.5194/acp-105641-2010, 2010.

Racherla, P. N. and Adams, P. J.: The response of surface ozone to climate change over the Eastern United States, Atmos. Chem. Phys., 8, 871-885, doi:10.5194/acp-8-871-2008, 2008.

Reuten, C., Ainslie, B., Steyn, D. G., Jackson, P. L., and McKendry, I.: Impact of climate change on ozone pollution in the lower Fraser Valley, Canada, Atmos. Ocean., 50, 42-53, doi:10.1080/07055900.2011.643444, 2012.

Rind, D., Lerner, J., Jonas, J., and McLinden, C.: Effects of resolution and model physics on tracer transports in the NASA Goddard Institute for Space Studies general circulation models, J. Geophys. Res.-Atmos., 112, D09315, doi:10.1029/2006jd007476, 2007.

Rosenstiel, T. N., Potosnak, M. J., Griffin, K. L., Fall, R., and Monson, R. K.: Increased $\mathrm{CO}_{2}$ uncouples growth from isoprene emission in an agriforest ecosystem, Nature, 421, 256-259, doi:10.1038/Nature01312, 2003.

Steiner, A. L., Tonse, S., Cohen, R. C., Goldstein, A. H., and Harley, R. A.: Influence of future climate and emissions on regional air quality in California, J. Geophys. Res.-Atmos., 111, D18303, doi:10.1029/2005jd006935, 2006.

Streets, D. G., Bond, T. C., Carmichael, G. R., Fernandes, S. D., Fu, Q., He, D., Klimont, Z., Nelson, S. M., Tsai, N. Y.,Wang, M. Q., Woo, J. H., and Yarber, K. F.: An inventory of gaseous and primary aerosol emissions in Asia in the year 2000, J. Geophys. Res.-Atmos., 108, 8809, doi:10.1029/2002jd003093, 2003.

Streets, D. G., Bond, T. C., Lee, T., and Jang, C.: On the future of carbonaceous aerosol emissions, J. Geophys. Res.-Atmos., 109, D24212, doi:10.1029/2004jd004902, 2004.

Tagaris, E., Manomaiphiboon, K., Liao, K.-J., Leung, L. R., Woo, J.-H., He, S., Amar, P., and Russell, A. G.: Impacts of global climate change and emissions on regional ozone and fine particulate matter concentrations over the United States. J. Geophys. Res.-Atmos., 112, D14312, doi: 10.1029/2006JD008262, 2007.

Tai, A. P. K., Mickley, L. J., and Jacob, D. J.: Impact of 2000-2050 climate change on fine particulate matter $\left(\mathrm{PM}_{2.5}\right)$ air quality inferred from a multi-model analysis of meteorological modes, Atmos. Chem. Phys., 12, 11329-11337, doi:10.5194/acp-1211329-2012, 2012a.

Tai, A. P. K., Mickley, L. J., Jacob, D. J., Leibensperger, E. M., Zhang, L., Fisher, J. A., and Pye, H. O. T.: Meteorological modes of variability for fine particulate matter $\left(\mathrm{PM}_{2.5}\right)$ air quality in the United States: implications for PM2.5 sensitivity to climate change, Atmos. Chem. Phys., 12, 3131-3145, doi:10.5194/acp12-3131-2012, 2012 b.
Tie, X. X. and Cao, J. J.: Erratum to "Aerosol pollution in China: Present and future impact on environment", Particuology, 8, 7979, doi:10.1016/j.partic.2009.12.001, 2010.

Unger, N., Shindell, D. T., Koch, D. M., Amann, M., Cofala, J., and Streets, D. G.: Influences of man-made emissions and climate changes on tropospheric ozone, methane, and sulfate at 2030 from a broad range of possible futures, J. Geophys. Res.-Atmos., 111, D12313, doi:10.1029/2005jd006518, 2006.

Wang, K., Zhang, Y., Jang, C., Phillips, S., and Wang, B.: Modeling intercontinental air pollution transport over the trans-Pacific region in 2001 using the Community Multiscale Air Quality modeling system, J. Geophys. Res.-Atmos., 114, D04307, doi:10.1029/2008jd010807, 2009.

Wang, Y. H., Jacob, D. J., and Logan, J. A.: Global simulation of tropospheric $\mathrm{O}_{3}$-Noxhydrocarbon chemistry. 1. Model formulation, J. Geophys. Res.-Atmos., 103, 10713-10725, doi:10.1029/98JD00158, 1998.

Wang, Y. H., Shen, L., Wu, S., Mickley, L. J., He, J., and Hao, J.: Sensitivity of surface ozone over China to 2000-2050 global changes of climate and emissions, Atmos. Environ., 75, 374-382, doi:10.1016/j.atmosenv.2013.04.045, 2013a.

Wang, Y. H., Zhang, Q. Q., He, K., Zhang, Q., and Chai, L.: Sulfatenitrate-ammonium aerosols over China: response to 2000-2015 emission changes of sulfur dioxide, nitrogen oxides, and ammonia, Atmos. Chem. Phys., 13, 2635-2652, doi:10.5194/acp-132635-2013, 2013b.

Wu, S. L., Mickley, L. J., Jacob, D. J., Logan, J. A., Yantosca, R. M., and Rind, D.: Why are there large differences between models in global budgets of tropospheric ozone?, J. Geophys. Res.-Atmos., 112, D05302, doi:10.1029/2006jd007801, 2007.

Wu, S. L., Mickley, L. J., Leibensperger, E. M., Jacob, D. J., Rind, D., and Streets, D. G.: Effects of 2000-2050 global change on ozone air quality in the United States, J. Geophys. Res.-Atmos., 113, D06302, doi:10.1029/2007jd008917, 2008.

Yienger, J. J. and Levy, H.: Empirical-model of global soil-biogenic $\mathrm{NO}_{\mathrm{x}}$ emissions, J. Geophys. Res.-Atmos., 100, 11447-11464, doi:10.1029/95JD00370, 1995.

Yu, H. B., Remer, L. A., Chin, M., Bian, H. S., Kleidman, R. G., and Diehl, T.: A satellite based assessment of transpacific transport of pollution aerosol, J. Geophys. Res.-Atmos., 113, D14s12, doi:10.1029/2007jd009349, 2008.

Zhang, L., Liao, H., and Li, J. P.: Impacts of Asian summer monsoon on seasonal and interannual variations of aerosols over eastern China, J. Geophys. Res.-Atmos., 115, D00k05, doi:10.1029/2009jd012299, 2010a.

Zhang, L., Liao, H., and Li, J.: Impact of the Southeast Asian summer monsoon strength on the outflow of aerosols from South Asia, Ann. Geophys., 28, 277-287, doi:10.5194/angeo-28-2772010, 2010b.

Zhu, J. L., Liao, H., and Li, J. P.: Increases in aerosol concentrations over eastern China due to the decadal-scale weakening of the East Asian summer monsoon, Geophys. Res. Lett., 39, L09809, doi:10.1029/2012g1051428, 2012. 